\title{
Diagnosis of Diseases of Steroid Hormone Production, Metabolism and Action
}

\author{
John W. Honour \\ University College London Hospitals, London, England
}

\begin{abstract}
Biochemical tests have been the basis for investigations of disorders affecting steroid hormones. In recent years it has been possible however to study the genes that determine functional enzymes, cofactors, receptors, transcription factors and signaling systems that are involved in the process. Analyses of mutations are available as a diagnostic service for only a few of these genes although research laboratories may be able to provide a service. Both biochemical and genetic research have brought to light new disorders. Some genes for transcription factors involved in the development of the endocrine organs have also been identified and patients with defects in these processes have been found. This paper will review general aspects of adrenal disorders with emphasis on clinical and laboratory findings. As with all endocrine investigations there are few single measurements that provide a definitive answer to a diagnosis. Timing of samples in relation to age, gender and time of day needs to be considered.
\end{abstract}

Keywords: Steroid, investigation, clinical findings

Received: $20.07 .2009 \quad$ Accepted: 24.08.2009
Biochemical tests have been the basis for investigations of disorders affecting steroid hormones. In recent years it has been possible however to study the genes that determine functional enzymes, cofactors, receptors, transcription factors and signaling systems that are involved in the process. Analyses of mutations are available as a diagnostic service for only a few of these genes although research laboratories may be able to provide a service. Both biochemical and genetic research have brought to light new disorders but for some patients a precise diagnosis may still not yet be achieved. Some genes for transcription factors involved in the development of the endocrine organs have also been identified and patients with defects in these processes have been found. Specific points about the steroid assays will be covered in a separate review. In general there is a lack of harmonisation of assays, an issue of concern which needs to be addressed. Where hormone concentrations are given in this review as action points these should not be used without reference to local experience and reference ranges for the analytical method in use. Tandem mass spectrometry is likely to replace the immunoassay procedures for steroids now being widely used; reference values are in general lower than has been the case before now. As with all endocrine investigations, there are few single measurements that provide a definitive answer to a diagnosis. Timing of samples in relation to age, gender and time of day needs to be considered. Appropriate reference ranges are needed. The regulation of a steroid needs to be taken into account. Test protocols should be agreed with the laboratory and adhered to in clinical practice. The laboratory should be given information about other drugs in use and clinical status of the patient (eg hypotensive). Any result that is unexpected should be discussed with the laboratory to exclude a procedural anomaly. A patient should be assessed clinically and

\section{Address for Correspondence}

John W. Honour, Clinical Biochemistry, University College London Hospitals, 60 Whitfield Street, London W1T 4EU England

E-mail: john.honour@uclh.nhs.uk

(c) Journal of Clinical Research in Pediatric Endocrinology, Published by Galenos Publishing. All rights reserved. 
biochemically before genetic tests are performed. Genetic tests will confirm the basis of the condition and provide a basis for treatment and genetic counseling. In some cases functional studies are needed to determine the effect on protein activity. Further genetic diseases may come to light from research based on patients with unusual clinical signs.

\section{Cortisol Hypersecretion}

High plasma concentrations of cortisol lead to combinations of a number of typical signs - moon-shaped face, buffalo hump, striae. The disease caused by a pituitary adenoma secreting adrenocorticotrophic hormone (ACTH) was first described by Cushing. This form is more frequent in boys than girls (1). Other causes of cortisol excess are classified under the generic name of Cushing's syndrome (Figure 1). Use of exogenous corticosteroids is the commonest cause of such problems and this should be excluded before investigations are taken further. Growth retardation and weight gain are the more likely presentation in a child with Cushing's syndrome. The high production of other steroids (more typical of adrenal tumours) accounts for acne, hirsutism, and in some cases for hypertension, although it is difficult to exclude direct effects of cortisol on blood pressure.

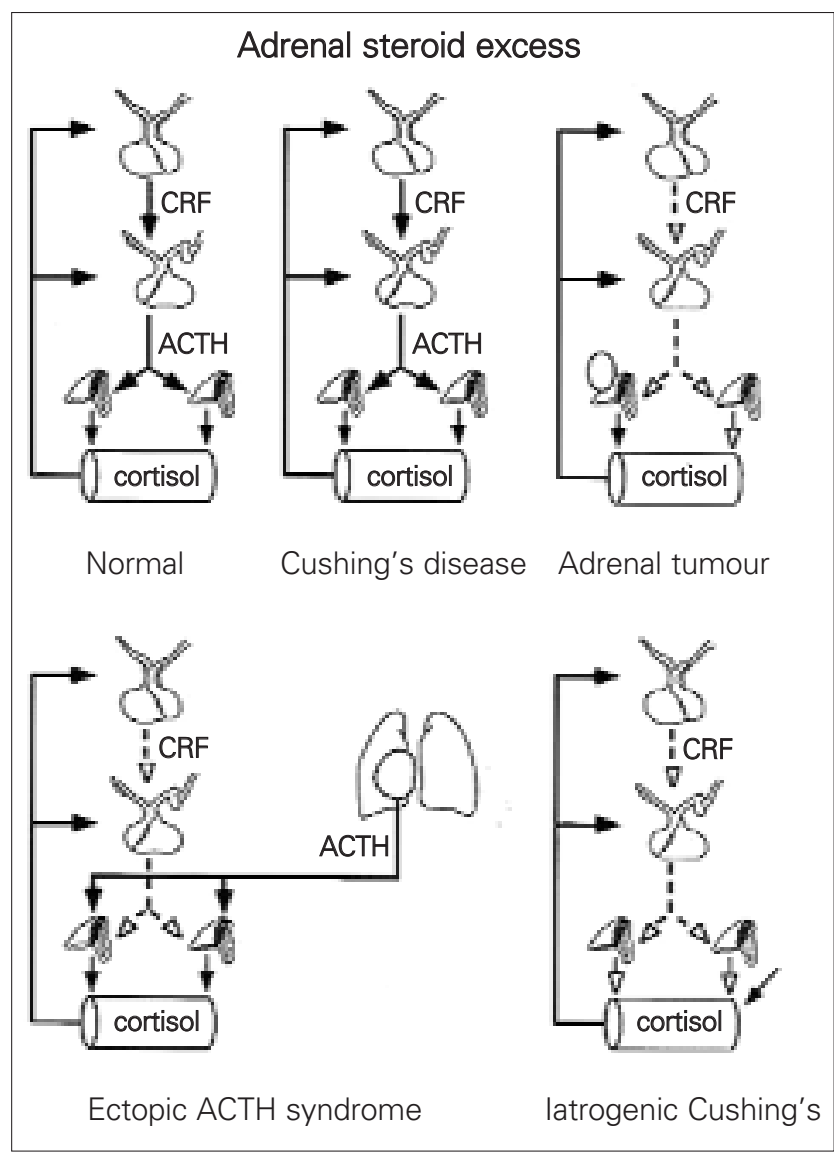

Figure 1. Adrenal steroid excess
Testing for Cushing's syndrome first requires the demonstration of excess cortisol production and then establishing the degree of autonomy of this production (2-4). Total cortisol concentration can be raised if CBG is elevated, for example, with exogenous oestrogens. A raised 24 hour urine excretion rate of free cortisol is a good indicator for the condition. This is commonly requested in the investigation of an obese patient. In addition to the methodological considerations of quantifying free cortisol in urine, there are the problems of obtaining complete 24 hour urine collections, especially in children. A high cortisol excretion rate may reflect stress on the day of collection, but in children the effects of alcoholism and psychiatric disorders seen in adults are unlikely.

Even if the urine cortisol excretion is clearly elevated (typically $>400 \mathrm{nmol} / 24$ hours), in the majority of patients tested, the urine free cortisol excretion will suppress to the lower region of the normal range after taking $0.5 \mathrm{mg}$ of dexamethasone every 6 hours for 2 days. The urine collection is made on the second day of treatment. Children less than $40 \mathrm{~kg}$ should get a dose of 30 micrograms per kg per day (5). Serum or plasma cortisol concentrations can be measured at 0800-0900 $\mathrm{h}$ after taking 1.0mg of dexamethasone at $2300 \mathrm{~h}$ as an alternative to this urine test. In children the dexamethasone dose is $0.3 \mathrm{mg}$ per metre squared (6). Plasma cortisol results above $50 \mathrm{nmol} / \mathrm{L}$ are abnormal. Accelerated dexamethasone metabolism is however, seen in patients taking certain medications, particularly anticonvulsants. In this regard, the simultaneous measurement of cortisol and dexamethasone can improve the diagnostic precision of the test. In a patient with high clinical suspicion of Cushing's, but normal urine free cortisol excretion rate on the first occassion, repeated $24 \mathrm{~h}$ urine collections over many weeks may be necessary since cyclical forms of the disease have been characterized, at least in adults, in this way with peak frequency over weeks to months.

The pattern of cortisol secretion in Cushing's syndrome is such that there is a loss of the diurnal rhythm of the serum concentrations of cortisol with noteably high levels in samples taken at midnight. In adults saliva samples have been used, but this has not been validated in children $(1,7)$. Further biochemical tests and imaging procedures are justified at this stage. The protocol will vary between hospitals depending upon the laboratory services, clinical practice and experience, and according to the availability of specialised tests eg ACTH assay, CT scanning.

Measurements of the plasma ACTH concentrations at midnight and 0800 hours are invaluable in the distinction of Cushing's syndrome. Circulating ACTH is low in patients with iatrogenic Cushing's or an adrenal tumour. In the ectopic syndrome, the serum ACTH measured by RIA is often very high. In considering assays for ACTH, the specificity of the RIA or IRMA should be known with respect to the measurement of ACTH itself, POMC and proACTH. The 
precursors can be measured by relatively specific IRMA and are found at high concentrations in patients with ectopic tumours (8). Chromagranin A may prove to be useful in the differentiation of ectopic tumours (9).

If ACTH assays are not available, dynamic tests can be used to gain further indications for the pathology of a patient with high cortisol production. An adrenal tumour will not usually respond to an $\mathrm{ACTH}$ stimulation test with an increased steroid output, but a hypersecreting adrenal will respond with a significant rise in serum cortisol concentrations. In contrast to the ACTH stimulated adrenal which secretes largely cortisol, adrenal tumours produce a spectrum of steroids such as dehydroepiandrosterone (DHA) or 17-hydroxy pregnenolone or other steroids and measurements of these, specifically or generally, can be arranged through specialised centres. Analysis of steroids in urine using capillary column GC and with mass spectrometry (urinary steroid profile analysis) may thus be the simplest way to reveal complex patterns of steroid production associated with tumours. This test an also confirm normal adrenal function should a mass be an incidentaloma. CT scanning may localise an adrenal tumour or display hyperplasia. Benign adrenal lesions associated with Cushing's syndrome are linked with dysregulation of cyclic AMP signaling, whereas tumours are linked to insulin-like growth factor II, p53 protein and related proteins (10).

The diagnosis of pituitary dependent Cushing's disease is confirmed when previously high cortisol production is substantially suppressed with high doses of dexamethasone (2 mg 6 hourly for 2 days) (1). Plasma cortisol, ACTH and urine free cortisol (or better of total cortisol metabolites) should all fall to less than $50 \%$ of their basal values in the majority of affected patients. In a meta-analysis of 3 tests (UFC, dexamethasone suppression and midnight cortisol alone and in combination) was effective in the diagnosis of Cushing's syndrome (11). Up to $10 \%$ of patients with ectopic ACTH secreting tumours can, however, suppress with the high dose of dexamethasone. The plasma concentrations of potassium and ACTH should therefore be checked since hypokalaemia and very high ACTH values by RIA are characteristic of the ectopic tumour. Other ectopic tumours such as carcinoid may not always be associated with hypokalaemia and ACTH may be only moderately raised. Hypokalaemia is found in a majority of cases with ectopic ACTH tumour. These cases are rare in children. The adrenals are enormous on CT and cortisol production is usually grossly elevated. A patient with an ectopic ACTH tumour may present with rapid onset weight loss, oedema and muscle weakness which is not the classical clinical picture of Cushing's syndrome.

The common failure to distinguish the pituitary dependent from the ectopic ACTH secreting tumour and fear of the consequences of incorrect surgery are the reasons for the interest in further tests. If a pituitary adenoma is suspected a CRF test may be informative in many cases (1). In Cushing's disease there is often an increase in cortisol above the normal response to intravenous $100 \mu \mathrm{g}$ CRF $11 \mu \mathrm{g}$ per $\mathrm{kg}$ in children). Blood samples are taken at $15 \mathrm{~min}$ before the CRF then at 0, 15, 30, 45, 60, 90 and 120 minutes. The combination of high dose dexamethasone and the CRF test with measurement of serum cortisol is superior to either test alone in the differential diagnosis of Cushing's syndrome. The interpretation of this test in children is confounded by severe obesity (12). Simultaneous measurements of $\mathrm{ACTH}$ and cortisol may improve the sensitivity and specificity of the test $(8,13)$. If an ectopic tumour is suspected, the pancreas and chest should be scanned by MRI, but it has to be said that the primary tumour is not always found (1). Venous catheter studies for the localisation of tumours producing ACTH may be valuable. The measurement of tumour markers such as CRF and calcitonin should be considered.

Sampling of blood bilaterally from inferior petrosal sinuses (BIPSS) for simultaneous assessment of ACTH concentrations is now used in older children in some specialised centres to differentiate Cushing's disease from the syndrome and for lateralisation of microadenoma (14). An intriguing observation from these studies has been the parallel increased secretion of prolactin, growth hormone, TSH and glycoprotein $\alpha$-subunit. These findings may reflect changes in the vasculature or a paracrine effect of $\beta$-endorphin from the tumour on adjacent tissue.

Primary nodular adrenocortical hyperplasia is an mportant cause of Cushing's syndrome in children and is usually associated with multiple endocrine neoplasia or Carney complex $(15,16)$. A paradoxical increase in UFC in the second phase of the high dose dexamethasone suppression test can be diagnostic $(17,18)$. McCune-Albright syndrome presents with Cushing's syndrome in children along with polyostotic fibrous dysplasia, café-au-lait skin pigmentation and precocious puberty (19). The syndrome is caused by activating mutations of the $\mathrm{G}$ protein alpha subunit (20).

Cortisone reductase deficiency is a rare cause of increased cortisol production because cortisone is not reduced to cortisol in the periphery. Patients present with a polycystic ovary picture without weight gain. Adrenal androgen output is raised because of the adrenal hyperplasia from high ACTH stimulation. Mutations can be found in the HSD11B1 gene and hexose-6-phosphate dehydrogenase $(\mathrm{H} 6 \mathrm{PDH})$ which is involved in NADPH regeneration for the enzyme (21). A urine steroid profile shows higher excretions of 11-oxo than 11-hydroxy cortisol metabolites (high ratio of THE plus cortolones to THF, allo-THF and cortols). A cortisone acetate challenge test is recommended to provide evidence to support the defects (22). Cortisol generation is lower than normal in patients with reductase defect.

High plasma cortisol concentrations and production rate can be seen in familial glucocorticoid resistance. Patients display signs of androgen and mineralocorticoid excess without the glucocorticoid effects $(23,24)$. Teenagers with resistant hypertension can show biochemical features of cortisol resistance (25), but so far the genetic basis of this has not been proven. 


\section{Adrenal Cortical Insufficiency}

Adrenal insufficiency may result from primary adrenal failure or secondary disease to impairment of the hypothalamicpituitary-adrenal axis (HPA) (26) and is life-threatening $(27,28)$. Although Addison in 1855 described tuberculous destruction of the whole adrenal glands, today autoimmune adrenalitis which spares the adrenal medulla is more common. In children, adrenal function is commonly impaired after long-term treatment with corticosteroids such as for asthma. This is an important clinical problem requiring tests, although there is no agreement on which tests should be performed. Morning plasma cortisol, urine free cortisol and cortisol response to $\mathrm{ACTH}$ are often used. Urine free cortisol is, however, a very poor test of adrenal suppression and measurements of total cortisol metabolites is much better (29). Congenital adrenal hyperplasia $(\mathrm{CAH})$ is a common cause of primary adrenal insufficiency that can be missed (28,30-32). Newborn screening based on determinations of blood spot 17-hydroxyprogesterone concentrations should pick up the 21-hydroxylase deficiency. A rapid result is needed to return an abnormal result before the onset of an adrenal crisis (presenting usually 5-10 days after birth). Hyperkalaemia before hyponatraemia can be early signs of $\mathrm{CAH}$, prolonged jaundice in a newborn infant may also be a sign of adrenal insufficiency. Other rare causes of adrenal insufficiency include infarction or haemorrhage and adrenal hypoplasia (particularly in newborn infants). Later adrenal destruction by metastases, sarcoidosis, histoplasmosis and amyloidosis may be found. Patients may have few or no symptoms of adrenal cortical insufficiency until they suffer a physical stress such as trauma, surgery or infection when they present with tiredness, weakness, lethargy, anorexia, nausea, weight loss, dizziness and hypoglycaemia. Pigmentation will sometimes be noted as a smokey brown coloration which affects the buccal mucosa (inside cheeks, gums and lips), on skin creases, scars, genitalia and areolae. This is a reflection of melanocyte stimulating hormone action which is a product of the proopiomelanocortin secreted by the pituitary along with ACTH. The patient will probably have postural hypotension with high plasma renin activity (PRA). The differential diagnosis of hypoglycaemia in childhood should include adrenal cortical insufficiency. This can be due to congenital adrenal hypoplasia (33) due to a primary defect in adrenal development or defects in ACTH synthesis, processing, release and response (familial glucocorticoid deficiency) (34).

Adrenal insufficiency is seen in disorders of cortisol production. Congenital adrenal hyperplasia in children often presents with symptoms due to excess or deficiency of sex steroids. Defects of 21-hydroxylase, 11 -hydroxylase and $3 \beta$-hydroxysteroid dehydrogenase are found with decreasing frequency and will be considered in more detail later in the review. Recently, an apparent combined deficiency of 21-hydroxylase and 17-hydroxylase was attributed to a defect in a common electron transporter called cytochrome P450 oxidoreductase (POR; ORD) (35-37). This defect can be associated with the Antley-Bixler syndrome. A raised 17-hydroxyprogesterone is suggestive of 21-hydroxylase, other steroids (progesterone and corticosterone) need to be checked if a POR defect is likely. A urine steroid profile is again a valuable test to cover these possibilities (38-40). Congenital adrenal hyperplasia due to defects of cholesterol uptake and cholesterol side chain cleavage enzyme (CYP11A1) $(41,42)$ can be lethal at an early stage, but there are exceptions (43) some present with hypospadias. The infants present as phenotypic females and have an adrenal crisis in the newborn period. Cholesterol uptake into mitochondria requires Steroidogenic Acute regulatory protein (StAR) and many mutations have been found in the gene $(44,45)$. Analysis of the genes involved in $\mathrm{CAH}$ has been critically reviewed (32) and will not be described in detail here. CYP21A2 mutations in Turkish children were summarized in this Journal (46). Several of the genes are duplicated on a chromosome to give active and inactive pairs (CYP21A2 and pseudogene CYP21B2), enzymes of different function (11-hydroxylase for cortisol synthesis - CYP11B1 and for aldosterone synthesis - CYP11B2) and enzymes of different tissue expression (HSD3B1 in periphery and HSD3B2 in adrenals and gonads). Care must be taken in the genetic tests to demonstrate mutations. Restriction enzyme digests, Southern blotting, polymerase chain reactions, specific oligonucleotide hybridization techniques, sequencing have been used.

A number of disorders of adrenal and gonadal development have been characterized in recent years. They present clinically and biochemically with inadequate or absence of adrenal and/or gonadal steroids. These include in boys defects of nuclear receptors DAX-1 and SF-1. Mutations in the NROB1 gene are found in the dosage sensitive sex reversal adrenal hypoplasia congenita on the X-chromosome, in the gene 1 (DAX-1) lead to neonatal adrenal insufficiency and failure to undergo puberty with hypogonadotrophic hypogonadism (47-51). Steroidogenic factor 1 (SF-1), a nuclear receptor, is expressed in adrenals and gonads, and mutations in the gene are found in some patients that present with adrenal failure and 46XY DSD (52-54).

The ACTH receptor gene (MC2R) has been found to have mutations in infants that present with glucocorticoid but not usually mineralocorticoid failure $(55,56)$. Mutations that inactivate proopiomelanocortin (POMC) have been described in children with adrenal insufficiency, early onset obesity and sometimes along with fair skin and red hair (57). Other pituitary transcription factor genes can be affected (PROP1, HESX1, OTX2, LHX4, SOX3) (see Reference 26 for recent summary), and others will come to light in the course of time.

Indications of Addison's disease in young males should prompt consideration of adrenoleukodystrophy $(58,59)$. Elevated levels of very long chain fatty acids (VLCFA) are found in plasma. Neurologic problems may or may not be present. The achalasia-Addisonian-alacrima syndrome (AAA), 
which appears to be autosomal recessive, is another example of combined adrenal and neurologic (autonomic) involvement (60). A gene for aladin on chromosome 12q3 is involved (61). Smith-Lemli-Opitz syndrome may present as ambiguous genitalia, and distinctive facial features, small head size (microcephaly). Malformations of the heart, lungs, kidneys, and Gl tract are also common. Infants with SmithLemli-Opitz syndrome have weak muscle tone (hypotonia), experience feeding difficulties, and tend to grow more slowly than other infants. Most affected individuals have fused second and third toes (syndactyly), and some have extra fingers or toes (polydactyly). A defect in cholesterol synthesis has been found and delta-7 steroids/sterols can be elevated in blood and urine $(62,63)$.

A good algorithm for the investigation of primary adrenal insufficiency in children has been published from the Department of Pediatrics in Montreal, Canada (30). Plasma cortisol concentrations between 7 and 9 am that are repeatedly less than $170 \mathrm{nmol} / \mathrm{L}$ are suggestive of adrenal cortical insufficiency. In a sick child cortisol concentrations of $300 \mathrm{nmol} / \mathrm{L}$ that do not increase on synacthen should be regarded as innappropriately low and worth investigating. This may not be seen, however, until the course of the disease has advanced. Low concentrations of cortisol in saliva also reflect Addison's disease (64). A short Synacthen test should be performed to assess adrenal reserve. Blood for serum cortisol is taken before and at 30 and 60 minutes after an intravenous injection of 250 micrograms of soluble Synacthen. Lower doses of synacthen (62.5 or 125 micrograms) should be used in young children. A normal response is characterised by an increment in cortisol of at least $200 \mathrm{nmol} / \mathrm{L}$ or a rise to levels above $500 \mathrm{nmol} / \mathrm{L}$. If an assay for cortisol is specific enough to exclude cross reaction with prednisolone this synthetic steroid can be given immediately after the basal blood has been taken so as to afford glucocorticoid cover without affecting the adrenal response to exogenous $\mathrm{ACTH}$. If there is pigmentation, the patient has primary adrenal failure (Addison's disease). Plasma ACTH measurements will be raised in Addison's disease and normal or low in secondary adrenal failure. A metyrapone test or insulin tolerance test can be helpful in distinguishing primary from secondary adrenal insufficiency. Circulating antibodies to the adrenal cortex suggest an autoimmune process and other endocrine tests may be required to look for an extension of the autoimmune process to other hormonal tissues. Cortisol should be replaced at 9-12 $\mathrm{mg} / \mathrm{M}^{2} / 24 \mathrm{~h}$ and it is useful to check cortisol concentrations throughout the day in plasma samples taken at 30 minute intervals over 2 hours after a morning dose of hydrocortisone, then at 2 to 3 hour intervals throughout the day. Depending on the frequency of sampling, cortisol concentrations above $700 \mathrm{nmol} / \mathrm{L}$ within an appropriate pattern reflects adequate replacement therapy.

Hyponatraemia is a frequent finding in primary adrenal insufficiency due to loss of mineralocorticoid steroids. The low plasma sodium is associated with hyperkalaemia and a raised plasma urea. In the urine there will be low potassium loss. In some cases the adrenal insufficiency may be part of more general hypopituitarism. If hypocortisolism is due to ACTH deficiency resulting from pituitary or hypothalamic disease such as tumours, infarction, trauma, there are usually other signs of deficiency of other hormones (eg loss of body hair). There will be no pigmentation. In the absence of ACTH, the production of aldosterone under the stimulus of the renin-angiotensin system will usually be unaffected and the blood pressure will probably be normal. Secondary adrenal insufficiency occurs when the adrenal cortex is deprived of ACTH stimulation. The commonest cause is after steroid therapy. An expanding pituitary tumour which leads to impairment of pituitary function usually affects the pituitary hormones in a sequential manner over a period of time. Growth hormone secretion fails first, followed by gonadotrophins, TSH and ACTH (65).

\section{Mineralocorticoid Excess}

Primary aldosteronism is extremely rare in children (66). Increased aldosterone secretion may be suspected in a patient presenting with muscle weakness due to hypokalaemia and headaches due to hypertension. Before the laboratory enters investigations of the renin-angiotensin-aldosterone system, abnormalities of electrolytes and water balance need to be confirmed. Many anti-hypertensive drugs affect plasma renin and aldosterone (thiazide and loop diuretics, beta-receptor blockers, calcium channel blockers) and these should ideally be stopped two weeks before meaningful tests can be carried out. Conn was the first in 1956 to describe an adrenal adenoma secreting aldosterone. The diagnosis of primary hyperaldosteronism rests in finding plasma aldosterone concentrations high for the corresponding PRA. Since removal of an adenoma corrects the blood pressure, localisation of the source of aldosterone assists a decision on the surgical approach for the operation.

Blood samples must be taken on several occasions for measurement of electrolytes. Patients with primary hyperaldosteronism have in the past been considered for investigation only when repeated plasma potassium values were below $3.7 \mathrm{mmol} / \mathrm{L}$. This is now not the case. Causes for potassium depletion (diarrhoea, purgatives, liquorice ingestion, diuretics) must be excluded. An algorithm for the diagnosis of primary aldosteronism in adults can be followed to reach a diagnosis of a rare paediatric problem (67). The tests should be conducted under medical supervision. Not all tests have been validated in children and may be difficult. A tumour may accumulate radiolabelled cholesterol. Catheterisation of the adrenal veins is in some centres a successful procedure in adults, but the venous drainage of the adrenal glands is often complex and even an experienced radiographer is not guaranteed of success. In a patient with an aldosterone secreting adenoma, the adrenal venous serum from the affected side usually shows a higher concentration of 
aldosterone compared with either the contralateral adrenal vein or the periphery sampled simultaneously. Aldosterone and cortisol should be measured in all samples to check the authenticity of the site from which the blood is taken. The cortisol concentrations in the adrenal vein samples may be in the order of $6000 \mathrm{nmol} / \mathrm{L}$. In children, idiopathic hyperaldosteronism in which the adrenals have a microor macronodular hyperplastic appearance has been described $(68,69)$. Surgery is not curative. The best treatment is with the aldosterone antagonist, spironolactone, or with amiloride.

Glucocorticoid remediable hyperaldosteronism is a rare familial cause of hypertension in which the biochemical features of hyperaldosteronism and the hypertension respond to glucocorticoid (dexamethasone) treatment (70). The hyperaldosteronism is responsive to ACTH but not to angiotensin II. This condition is associated with increased excretion of 18-oxocortisol which may arise by 18-hydroxylation of cortisol in the adrenal zona fasciculata due to a protein from a chimeric gene of CYPB11B1 and CYP11B2 (71). Estimation of 18-hydroxycortisol is likely to prove useful in screening for this disorder $(72,73)$, but this assay has limited availability. An increased urine excretion of the steroid can be seen in a urine steroid profile. Genetic testing is available (74).

Diuretic therapy is the commonest cause of secondary aldosteronism. PRA is raised as a physiological response to hypovolaemia (haemorrhage or intestinal fluid loss). Renin secretion is increased with renal ischaemia, renal artery stenosis. Peripheral PRA levels may be only moderately raised, but renal vein samples may show a result on the ischaemic side 1.5 times or more that from the contralateral normal kidney.

Hypokalaemia without hypertension is the result of increased aldosterone, but certainly in adults can be due to diuretic or laxative abuse or psychogenic vomiting. Salt loss with hypokalaemic alkalosis and hypercaliuria are found with renal tubulopathies (Bartter syndrome) in the distal convoluted tubules and/or loop of Henle (75). An infant with polyhydramnios may have one form of Bartter's syndrome needing genetic analysis to distinguish them (76). Hypokalaemic alkalosis is due to a renal tubular defect from a mutation in the renal outer medullary potassium channel (Type 2 ROMK now KCNJ1) or the sodium/potassium/2 chloride transporter (Type 1 SLCl2A1 now NKCC2). The infantile form is associated with growth failure and sensorineural deafness. The primary cause for this disorder (type 3 ) is due to mutations in the chloride channel gene (CLCNKB) (76). Type 4 has simultaneous mutations in BSND and CLCNKB or CLCNKA. There is resistance of the vasculature to the pressor action of angiotensin II associated with a compensatory increase in PRA with juxtaglomerular hyperplasia. The plasma concentrations of both aldosterone and PRA are raised. The Gitelman variant can present in childhood with growth delay, metabolic alkalosis, hypokalaemia and hypomagnesaemia. Mutations are found in the chloride transporter SLCI2A3 gene (77).
Low PRA may be encountered when mineralocorticoids other than aldosterone are in excess. This can be due to $\mathrm{CAH}$ due to $11 \beta$-hydroxylase deficiency or $17 \alpha$-hydroxylase deficiency (11-deoxycorticosterone DOC excess) $(31,32,78)$ or with mineralocorticoid secreting tumours. All are rare. A defect in CYP11B1 presents with ambiguous genitalia in girls and precocious puberty in boys (79). 17-hydroxylase deficiency is not usually detected until a female is investigated for primary amenorrhoea and lack of sexual development. Persistent high progesterone is a useful diagnostic clue to this defect (80). The increased plasma corticosterone concentrations have been demonstrated by HPLC with UV detection (81). In a syndrome of apparent mineralocorticoid excess (AME) there is hypertension, hypokalaemia and reduced secretion rate of cortisol. The improvement brought about by treatment with spironolactone (aldosterone antagonist) or triamterine (potassium sparing diuretic) suggested the presence of an unidentified mineralocorticoid. The disease is attributed to cortisol acting as both glucocorticoid and mineralocorticoid with a prolonged half-life due to low activity of $11 \beta$-hydroxysteroid dehydrogenase type 2 (which normally oxidises cortisol to inactive cortisone) (82). This defect is most easily detected by a urine steroid profile which clearly displays a high excretion of cortisol metabolites relative to cortisone (83). Tandem mass spectrometry methods have enabled simultaneous analysis of cortisol and cortisone in blood (84-86) and saliva (87), and of metabolites in urine (88). The disease has been found mainly in children with severe hypertension and may be lethal which may explain why very few adult cases have been described. The mineralocorticoid activity of liquorice is now known to be due to inhibition of the enzyme system 11ß-hydroxysteroid dehydrogenase. Patients should be asked about confectionary habits (89).

Primary hypoaldosteronism with hyperkalaemia, increased PRA and low aldosterone concentrations is due to Addison's disease, congenital adrenal hypoplasia, or defects of aldosterone synthesis most commonly due to $\mathrm{CAH}$. PRA and aldosterone are rarely subnormal, but this secondary hypoaldosteronism is found in association with diabetes, chronic renal disease and as an isolated occurrence.

Hyponatraemia in the neonatal period is an urgent diagnostic problem which should consider whether the sodium intake is adequate $(<4 \mathrm{mmol} / \mathrm{kg} /$ day in term babies, up to $12 \mathrm{mmol} / \mathrm{kg} /$ day in preterm infants), the water intake is high or there is sodium loss from the gastrointestinal tract or kidneys. Renal salt loss can be due to anatomical abnormalities, obstructive or renal tubular disorders which can include failure to respond to aldosterone. Low production of mineralocorticoid due to adrenal disease is a common cause of salt loss with hyperkalaemia in newborns.

A male child who collapses during the second week of life should be tested for $\mathrm{CAH}$ due to 21-hydroxylase deficiency. Sixty percent of all children with this defect show this salt-losing variant of the disease. The enzyme deficiency in cortisol production extends to the synthesis of aldosterone. 
Plasma renin activity will be elevated and aldosterone will be inappropriately low. Since plasma renin activity is higher in all newborn infants than in adults it is important to check the activity against a normal range for age of the infant (90). A defect in 3 $\beta$-hydroxysteroid dehydrogenase, side-chain cleavage, StAR or adrenal hypoplasia may also explain the salt-losing state so other tests such as a urine steroid profile should be organized.

If the biosynthetic path to cortisol is normal, the production of aldosterone needs to be evaluated. Defects of aldosterone production and action are recognised. In both cases PRA will be elevated, the defects are distinguished by the serum concentrations of aldosterone or urine excretion rates of the metabolites. A defect in the late steps of aldosterone biosynthesis will be confirmed when 18-hydroxycorticosterone production is shown to be elevated in blood (91) or urine (92). Mutations have been found in CYP11B2 by sequencing (93).

Corticosterone, 18-hydroxycorticosterone and aldosterone are elevated through renin/angiotensin stimulation in disorders of aldosterone receptor and the gene NR3C2 encoding the mineralocorticoid receptor can have mutations in some (pseudohypoaldosteronism - PHA) (94-97). This is an autosomal dominant form of PHA1. A more common form is due to mutations of the epithelial sodium transport channel (ENaC) $(98,99)$. The biochemical diagnosis is straightforward if the child is sodium depleted (100). In children with the receptor defect the salt loss seems to be partially correctable by increasing the dietary salt intake to satisfy salt craving.
Aldosterone receptor resistance has been demonstrated in assays of electrolyte transfer by mononuclear leucocytes (101), but this is not generally available.

Hyponatraemia is often seen in the first weeks of life in preterm infants (<30 weeks gestation) (102). This reflects immaturity of renal function as well as in the adrenal production of aldosterone and the diuretic effect of increased vasopressin production $(103,104)$.

\section{Androgen Excess}

The investigations of androgen excess have different objectives depending on the age and karyotype of the patient. Thus 46,XX girls present with ambiguous genitalia usually due to inherited metabolic disease (congenital adrenal hyperplasia, CAH) of the adrenal cortex. During childhood boys with precocious puberty may have space occupying lesions of the brain, $\mathrm{CAH}$ or very rarely tumours of the adrenals or gonads. A few girls with hirsutism and/or acne with or without menstrual disturbance may have non-classic $\mathrm{CAH}$ or very rarely have excess secretion of androgens of ovarian or adrenal origin due to tumours. Polycystic ovaries are commonly found in mild hyperandrogenisation in adolescence that may progress to infertility in adult life.

In newborn girls with ambiguous genitalia (46XX DSD), the commonest cause is due to enzyme defects of cortisol synthesis with diversion of intermediates to androgen

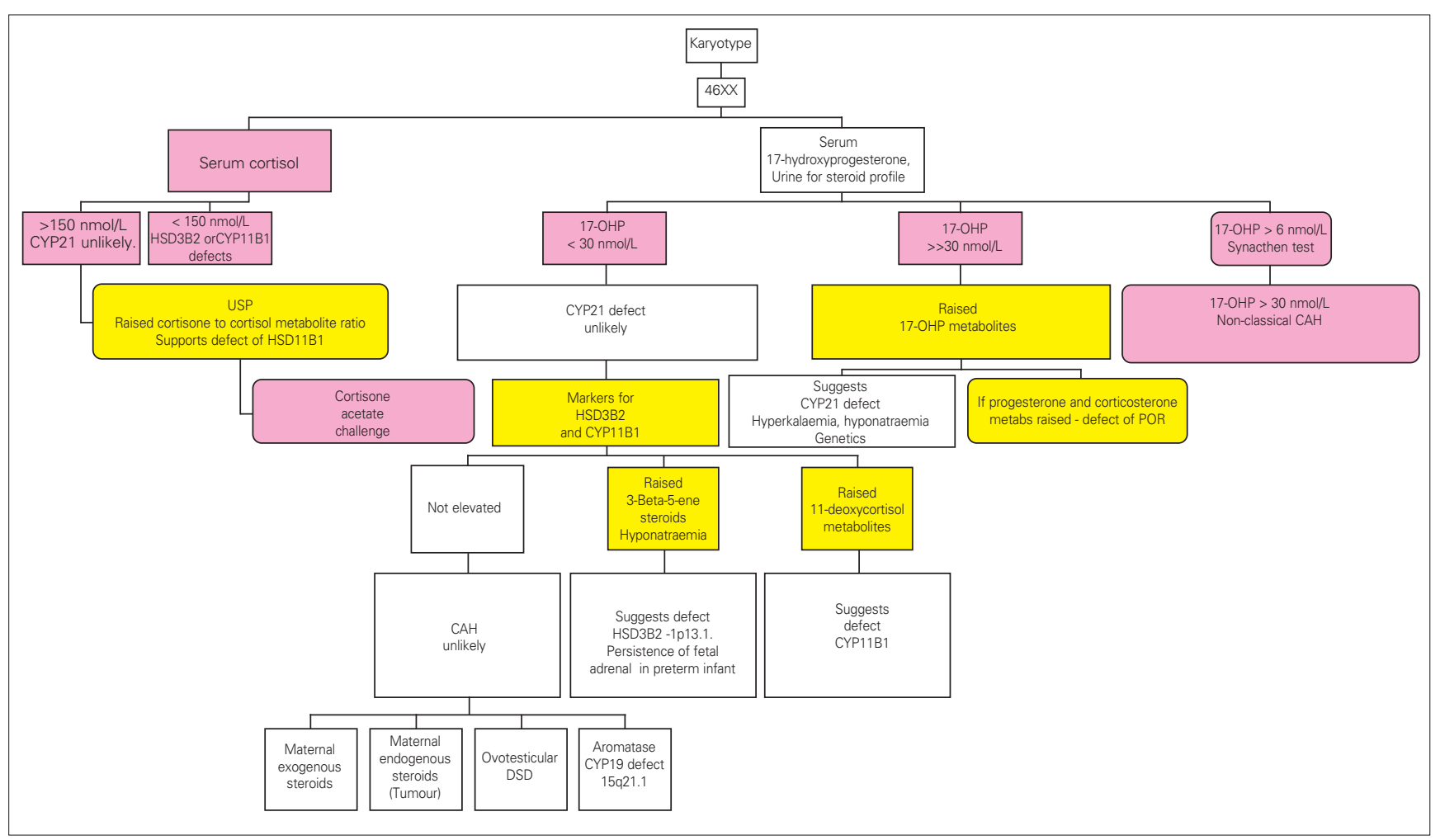

Figure 2. Androgenised female 46XX 
production (31,32) (Figure 2). The genotype should be confirmed by chromosome analysis. A pelvic ultrasound may also be helpful, but results need to be treated with some caution. Other external causes of a virilised female are attributed to aromatase deficiency (105) and an ovotesticular DSD (106), maternal ingestion of progestogens (now very rare) or androgens or to maternal production of androgens by an adrenal or ovarian tumour. In these cases, the child will have normal endocrinology after birth, but may need surgery on the external genitalia if androgenisation is severe.

A reduction in steroid 21-hydroxylase activity or absence of $11 \beta$-hydroxylase or $3 \beta$-hydroxysteroid dehydrogenase can be the cause of $\mathrm{CAH}$ of which 21-hydroxylase deficiency is by far the commonest cause of $\mathrm{CAH}$ ( $90 \%$ of cases). In Europe, $60 \%$ of all cases of steroid 21-hydroxylase deficiency will present in the newborn period with a salt-losing crisis. This reflects the nature of the enzyme block. If there is a salt-losing crisis, this will need immediate treatment. An increase in serum potassium may be seen prior to a fall in body weight and hyponatraemia.

$17 \alpha$-hydroxyprogesterone is a biosynthetic precursor of cortisol and in patients with deficiency of 21-hydroxylase the production of 17-OHP increases and serum levels are elevated. The reduced capacity to produce cortisol, however, leads to high ACTH levels which cause adrenal hyperplasia. There is also a high adrenal secretion of androgens which cause virilisation. The measurement of $17-\mathrm{OHP}$ in serum, plasma and blood spots is used for the diagnosis of this disorder. The timing of blood sampling is very important in order that the laboratory can interpret the findings. In all newborn infants, 17-OHP concentrations in serum are high on the first day of life ( $>100 \mathrm{nmol} / \mathrm{L})$ and the levels fall over the first week to below $50 \mathrm{nmol} / \mathrm{L}$. After day 3, there is usually good discrimination of the 17-OHP in affected cases (100-800nmol/L) from normal infants ( $<15 \mathrm{nmol} / \mathrm{L})$. Differences in results with a direct and an extraction method would suggest that steroids in blood (probably steroid sulphates from the fetal adrenal) cross react in the RIA giving higher results in the direct assay $(107,108)$. The suggestion that steroid sulphates affect the quality of the assay is supported on the observation of greater discrepancy between the results obtained by the 2 methods in premature and low birth weight babies both of which have sustained fetal adrenal activity after birth. 17-OHP can be mildly elevated in defects of HSD3B2, POR and CYP11B1.

In rare cases of $\mathrm{CAH}$, the defect is due to low activity of the $11 \beta$-hydroxylase enzyme (79). This defect is best identified by a raised serum concentration of 11-deoxycortisol or by a urine steroid profile. A high excretion of 6-hydroxy-tetrahydro11-deoxycortisol (6-hydroxy-THS) is a better marker of the defect in the newborn than THS which is elevated in older patients (>120 nmol/L) but not so clearly raised in the newborn period (109). This again emphasises the requirement to involve specialised laboratories with relevant experience.
The cause of ambiguous genitalia in a newborn child is required as soon as possible in order to counsel anxious parents and start treatment. A 17-OHP assay which involves solvent extraction before the RIA is essential. Now that specific urine metabolites of 17-OHP have been recognised, the diagnosis by GC analysis of steroids in urine is reliable. Pregnanetriol is one marker for the disorder in the newborn. A characteristic urine steroid pattern can be recognised of which the most informative steroid is $17 \alpha$-hydroxypregnanolone. It is essential that a laboratory offering this analysis can provide a rapid service ( $<2$ days). In order to achieve this, the identity of the steroids in the GC analysis must be confirmed by a further analysis with GC coupled to a mass spectrometer. Some laboratories now offer simultaneous analysis of several steroids by using GC-MS (110) or LC coupled with tandem mass spectrometry (111-114). These tests enable one of several forms of $\mathrm{CAH}$ to be detected and will become important on regional or national basis. Newborn screening has been based on immunoassay of steroids in blood spots. Repeat testing has eliminated the disease when the concentrations of 17-OHP were lower than an initial high level that suggested 21-hydroxylase deficiency (115); this approach is stressful to the family. False positive results are reduced by the use of cut-off levels adjusted for gestation age or birth weight, and by solvent extraction of steroids (116). Screening will also improve with more specific technology based on tandem mass spectrometry (117-119).

Once $\mathrm{CAH}$ has been confirmed and lifelong cortisol treatment has commenced, compliance is best assessed in children by following growth (120). Height and weight should be followed at 3 monthly intervals in the first 2 years of life, then at 6 monthly visits. Bone age is checked yearly from $X$-rays of the wrist and hands. The replacement therapy should be adjusted according to body size. Hydrocortisone is usually prescribed at $9-12 \mathrm{mg} / \mathrm{M}^{2} /$ day with $2 / 3$ of the dose in the morning and $1 / 3$ in the evening. If fludrocortisone is given, to control salt loss it must be remembered that this steroid is a potent glucocorticoid itself and the dose should not exceed $0.15 \mathrm{mg} / \mathrm{M}^{2}$. Sodium supplements may be needed in infancy. Electrolytes can be measured periodically, but for long term assessment of mineralocorticoid replacement the measurement of plasma renin activity is advisable. The measurement of $17-\mathrm{OHP}$ and androgens in blood (or saliva) taken at regular intervals will define the adrenal steroid output in relation to treatment, but in practice has little effect on a patients drug taking habits. Androstenedione measurements may be helpful in the management of $\mathrm{CAH}$ due to 21-hydroxylase and 11 $\beta$-hydroxylase defects. Measurement of PRA can be used to monitor efficacy of treatment in salt-losing $\mathrm{CAH}$. Patients with 21-hydroxylase and some with $3 \beta$-hydroxysteroid dehydrogenase defects manifest elevated PRA, while in the defects with mineralocorticoid excess ( $17 \alpha$-hydroxylase and 11 $\beta$-hydroxylase) PRA is suppressed. PRA is normalised with effective treatment. In the case of 21-hydroxylase deficiency and $3 \beta$-hydroxysteroid dehydrogenase defects, treatment is improved with addition of fludrocortisone. 
When sexual maturation appears before 8 years in girls and 9 years in boys, puberty is considered precocious. The diagnosis of precocious puberty was reviewed recently in this Journal (121). Normal puberty is initiated by an increase in pulsatile secretion of $\mathrm{GnRH}$ at night, although the mechanism and timing of this initiation is still not understood. Failure to find a pelvic mass by palpation or ultrasound scan reduces the likelihood of a rare ovarian tumour. Central precocious puberty (gonadotrophin dependent precocious puberty) reflects early activation of the gonadotrophic drive to increased gonadal function. This is more common in girls than in boys. A child with clinical precocious puberty who has pubertal gonadotrophin levels and augmented nocturnal gonadotrophin secretion has central precocious puberty $(122,123)$. LH results should be treated with caution because of interference from heterophilic antibodies and high results should be confirmed using a second assay (124). Assays have been devised to avoid such interference $(125,126)$. In girls, pelvic ultrasound is useful for the assessment of central precocious puberty (122). CNS tumours (hamartomas, third ventricular cysts, astrocytomas or gliomas) can be recognised by MRI. Some of the tumours (dysgerminomas, hepatoblastomas) secrete hCG. A cerebral tumour is relatively more common in boys with central precocious puberty than in girls.

Gonadotrophin independent precocious puberty is due to inappropriate production of gonadal or adrenal hormones which affect secondary sex characteristics. Children may have acne and behavioural problems and may become taller than their peers. As a result of rapid skeletal maturation there is early epiphyseal fusion and the outcome is for short stature in adulthood. Hypothyroidism should be excluded. With the increase in TSH there is a concomitant increase in FSH and prolactin that presumably leads to sexual precocity. In patients with the McCune-Albright syndrome, precocious puberty is associated with cafe-au-lait skin marks and polyostotic fibrous dysplasia (19). Plasma gonadotrophin concentrations are often pubertal, but may in some cases be prepubertal. Symptoms may wax and wane and on ultrasound this can be attributed to the appearance and regression of unilateral ovarian cysts. Up to $80 \%$ of girls and $40 \%$ of boys with precocious puberty may have no responsible cause and are termed idiopathic.

Pseudo-precocious puberty can be the result of exposure to exogenous sex steroids. Both contraceptive pill and anabolic steroids are reported offenders. Abnormal sex steroid secretion from tumours is also a cause. The most common adrenal tumour reported in the literature secretes DHAS. In general the tumours have been quite large. A number of cases of tumours secreting other androgens have been reported and using urine steroid profile analysis, the secretion of $11 \beta$-hydroxyandrostenedione has been defined on the basis of high excretion of 11 1 -hydroxyandrosterone $(127,128)$. In these reported cases androgen excretion was not grossly elevated and without scanning of the adrenals a tumour may have been dismissed. FSH and LH are suppressed to within prepubertal ranges. The secretion of androgens by adrenal tumours is not suppressed by giving dexamethasone. A testicular mass with grossly elevated 17-OH-P usually indicates $\mathrm{CAH}$ with adrenal rests in the testes. Leydig cell tumours, however, may produce elevated $17-\mathrm{OH}-\mathrm{P}$, which is not suppressed with dexamethasone. 21-deoxycortisol is not raised in these cases, unlike the situation with $\mathrm{CAH}$. One recent report of premature pubarche described a child with hyperandrogenic anovulation, who had low plasma DHAS due to defect of the sulphotransferase SULT2A1 through a defect in sulphate delivery from PAPS through inactivating mutations in PAPSS2 (129).

Pubic hair growth before breast development or testicular enlargement may be the outcome of increased secretion of DHA and DHAS from the adrenal cortex due to early differentiation of the zona reticularis. This is a benign disorder called premature adrenarche not requiring treatment. DHA and DHAS concentrations in serum should be interpreted against normal ranges for age. Testosterone may be slightly elevated for age due to peripheral conversion of the adrenal androgens. The 24 hour urine excretion of androsterone, aetiocholanolone as well as cortisol metabolies are above the normal range for age and body size (Figure 3) reflecting advance adrenal growth. Premature adrenarche is more common in Asian and Afro-Caribbean children than Caucasians.

Acne, hirsutism, menstrual disturbance can be due to non-classical forms of $\mathrm{CAH}$ and a mild defect of the steroid 21-hydroxylase. In many such patients, the basal 17-hydroxyprogesterone concentrations are above the normal range (>5 nmol/L). An injection of ACTH will lead to an increase in serum 17-OHP at 30 and 60 minutes after the trophic hormone injection and affected subjects will have an increment in 17-OHP greater than seen in normal

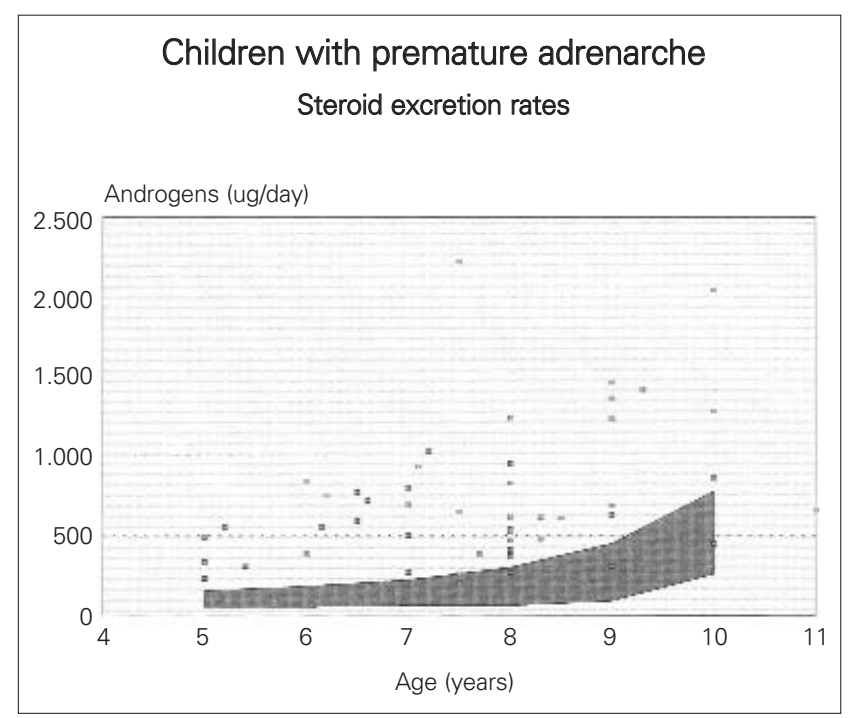

Figure 3. Children with premature adrenarche 
subjects (Table 1) (130). Fifty percent of patients with non-classic or late onset form of CAH have HLA B14, DR1 in association, since this is coded nearby on the short arm of chromosome 6 and specific mutations in exon 1 or exon 7 CYP21A2 (V281L; P453S) (131). A late onset form of $3 \beta$-hydroxysteroid dehydrogenase deficiency was suggested on the basis of exagerated DHA or 17-hydroxypregnenolone response to ACTH (132), but mutation analysis does not support this aetiology $(133,134)$.

Some girls present with isolated breast development (premature thelarche) and no growth acceleration (135). Increased oestrogen production in girls with premature thelarche is a benign condition not to be confused with central precocious puberty. There is no increase in growth rate. The latter is more serious and causes progressive breast development with pubic hair growth, accelerated growth rate and bone maturation and early epiphyseal fusion. A pelvic ultrasound may show a follicle in the ovary. The two conditions have been resolved by repeated blood sampling at 15 minute intervals throughout the night (122). In patients with thelarche the FSH is higher (2-7 iu/L) than the $\mathrm{LH}$ (1-3 iu/L), which contrasts with precocious puberty where $\mathrm{LH}$ secretion predominates. A $\mathrm{GnRH}$ stimulation test may sometimes be needed to distinguish the 2 disorders again by revealing differences in the prodominant gonadotrophin, but interpretation may be assay dependent $(136,137)$. Various doses of $\mathrm{GnRH}$ are used with 10 microgram and 100 microgram (being the most common) with blood samples at zero, 20 and 60 minutes. Peak LH usually occurs at $20 \mathrm{~min}$ and peak $\mathrm{FSH}$ at 60 minutes after injection of $\mathrm{GnRH}$.

\section{Androgen Deficiency}

Incomplete androgenisation of a 46XY fetus is due to a failure of sex steroid production or to resistance to these hormones because of receptor defects. Most laboratories will need the help of specialised centres to resolve such cases, although a number of investigations can be undertaken locally. Following confirmation of chromosomes, the serum concentrations of cortisol and testosterone should be checked. From these results some clear decisions can be made. Defects of sex steroid production can be separated into:

- those affecting cortisol and androgens and (Figure 4)

- those relating to androgens alone (Figure 5)

Poor androgenisation of a 46XY male (46XY DSD) with low cortisol production can be attributed to defects of StAR, cholesterol 20,22 desmolase (side-chain cleavage, CYP11A1), 17 $\alpha$-hydroxylase deficiency, or of $3 \beta$-hydroxysteroid dehydrogenase type 2 (Figure 4). These enzymes affect the production of all important adrenal and gonadal steroid hormones and disorders of the enzymes are often

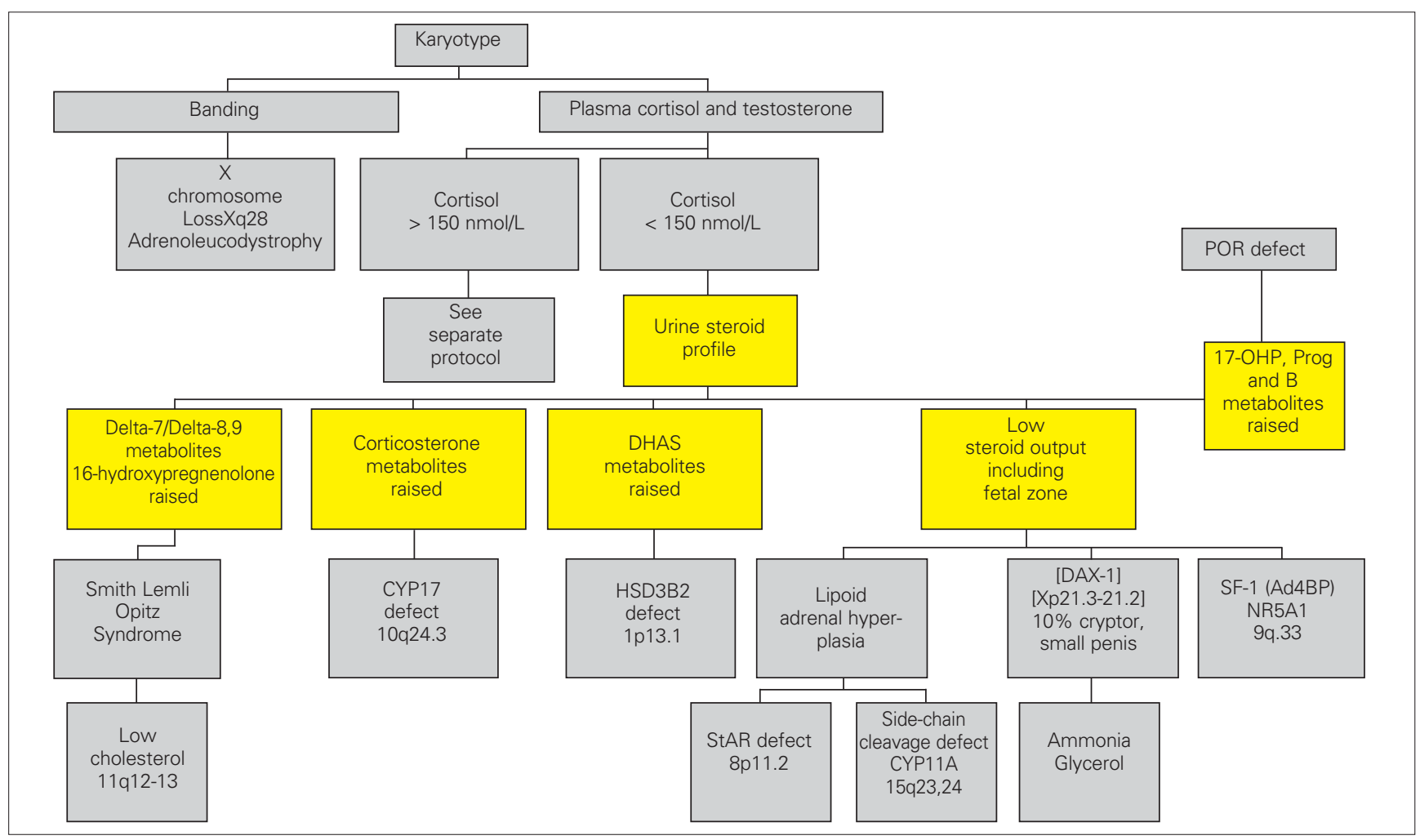

Figure 4. Poorly androgenised male, low cortisol (* can be $\geq 150 \mathrm{nmol} / \mathrm{L}$ unwell) 
fatal for the child, so that few cases are documented in the literature. StAR deficiency is also called lipoid adrenal hyperplasia on account of the histological appearance of the adrenals at post mortem reflecting the ACTH stimulated adrenal which cannot produce cortisol nor process cholesterol.

Defects of $17 \alpha$-hydroxylase $(78,81,138)$ and $3 \beta-O H-S-D H$ are identified biochemically by demonstrating high serum levels and urine metabolites of the respective enzyme substrates (Table 1). The pattern of steroids in urine of a neonate, later confirmed to have $17 \alpha$-hydroxylase deficiency, showed high excretion rates of $16 \alpha$-hydroxypregnanolone. At 15 months of age the child excreted corticosterone metabolites just as is found in urine of adults with this disease (139). Mutations in CYP17 have been confirmed by sequencing $(78,81,138,140)$. A 3 $\beta$-hydroxysteroid dehydrogenase deficiency is in practice difficult to confirm in a newborn child because the markers for the defect (DHA and pregnenolone) are normal products of the adrenal in the

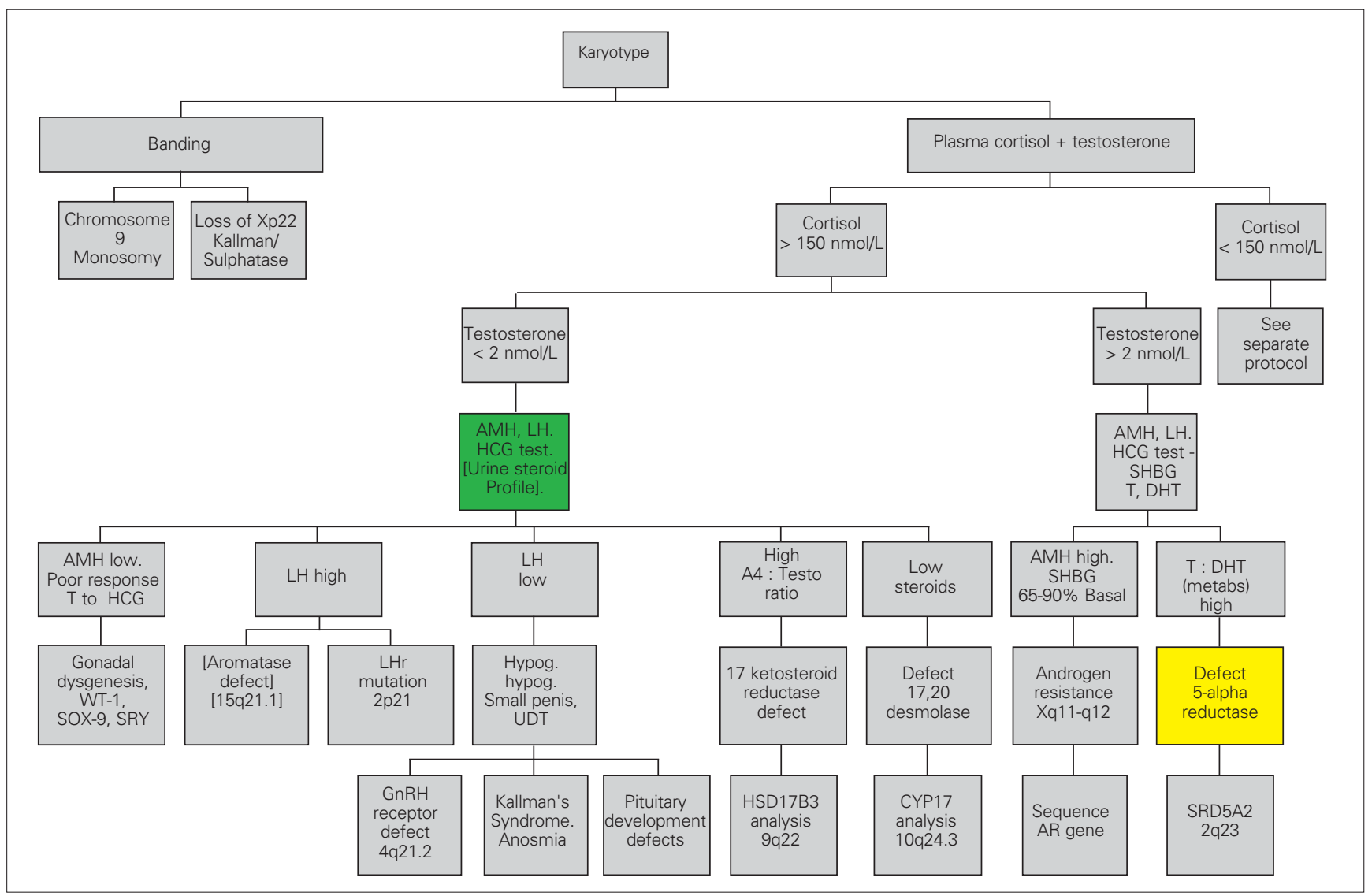

Figure 5. Poorly androgenised male, normal cortisol production (N.B. cortisol cut off can be $>300 \mathrm{nmol} / \mathrm{L}$ if unwell)

Table 1. 17-OHP by GC-MS - Reference ranges

\begin{tabular}{|c|c|c|}
\hline & Basal (nmol/L) & 30 minutes post synacthen (nmol/L) \\
\hline Normal neonate (beyond second day) & $<3$ & \\
\hline Normal child $1-6$ yrs & $<3$ & $<8$ \\
\hline Normal child 6-10 yrs & $<5$ & $<10$ \\
\hline Patient with classical CAH due to CYP21 defect & $>100$ & $\gg 200$ \\
\hline Patients with non-classical CAH & $5-200$ & $60-800$ \\
\hline Heterozygotes for classical CAH & $<10$ & $5-50$ \\
\hline Normal adult males $0800-1000 \mathrm{~h}$ & $1.2-5$ & $3-10$ \\
\hline Normal adult females (follicular phase) & $0.6-4.0$ & $2-8$ \\
\hline Normal adult females (luteal phase) & $1.0-6$ & $2-10$ \\
\hline
\end{tabular}


newborn due to inactivity of this enzyme in the fetal adrenal cortex. A 24 hour urine collection with determination of excretion rates of all steroids is therefore needed. Since these infants are usually very sick, this is not straightforward. Plasma measurements of DHA and ACTH may be better tests before treatment, but in the face of an adrenal crisis replacement therapy may be needed before the necessary tests are completed. To overcome this problem dexamethasone is the preferred treatment. If a child suspected of having $3 \beta$-hydroxysteroid dehydrogenase deficiency is switched to treatment with dexamethasone and fludrocortisone then given daily injections of depot ACTH (Synacthen), the markers for the defect can be displayed in the urine steroid profile without interference from dexamethasone. This approach has been used successfully in confirming $3 \beta-\mathrm{OHSDH}$ deficiency during maintainance with hydrocortisone for several years, although ACTH was needed for several days before the suppressed adrenal secreted sufficient steroid to be detected in the urine steroid assay. Males with defects in HSD3B2 can be reared as boys needing adrenal steroid replacement with the addition of androgens at puberty. Mutations are located in HSD3B2 in regions coding for domains crucial for enzyme function $(134,141)$. SmithLemli Opitz syndrome is a dysmorphic disorder with microcephaly, short nose, pyloric stenosis and cleft palate. Cholesterol synthesis fails at the 7-dehydrocholesterol reduction step and 7-dehydro steroids can be found in the urine of an infant with this condition (142).

The further investigation of males with poor androgenisation and normal cortisol will depend upon the initial findings for testosterone and gonadotrophins. A low basal testosterone with elevated gonadotrophins and a poor androgen response to HCG suggest either Leydig cell hypoplasia $(\mathrm{LCH})$ or an androgen biosynthetic defect. Mutations in the $\mathrm{LH}$ receptor gene are responsible for $\mathrm{LCH}(143,144)$. A high ratio of androstenedione to testosterone in the basal state, exagerated or revealed by HCG stimulation (ratio $>2$ ) suggests a defect of 17-ketosteroid reductase and genetic testing of 17BHSD3 may be needed (145-147). The immunoassays in use for androgens are not accurate in young children. A male with this defect can be reared as a boy but will need testosterone treatment. Improved, simultaneous androgen assays by tandem mass spectrometry will aid the diagnosis of DSD (148-151).

A normal basal testosterone with a rise following HCG suggests that the problem is due to impaired action of testosterone. This can be due to a failure of target tissue $5 \alpha$-reductase or to receptor defects. Specialist help will be needed to resolve this problem. A high testosterone to $5 \alpha$-DHT ratio (>20) after HCG stimulation supports $5 \alpha$-reductase deficiency. In a urine steroid profile there is evidence for this disorder also in the distribution of cortisol metabolites ( $5 \alpha$-THF to THF) in childhood. In newborns, however, the majority of cortisol metabolites have been oxidised to cortisone metabolites and there is very little of the cortisol metabolites to effectively confirm this diagnosis. This test should therefore not be performed in the first six months. In that period, blood samples for androgens can be taken, because LH secretion is not suppressed (152). Missense and nonsense mutations in SRD5A2 have been reported $(153,154)$. Androgen receptor defects can influence the number and stability of androgen receptors. Genital skin needs to be taken and sent to a specialist laboratory. The cells have to be increased in number by culturing through several passages in tissue culture before these experiments can be undertaken. Receptor gene analysis is available in a few centres (155-159). Increased ratios of $5 \alpha$ to $5 \beta$ reduced androgens have been found in association with Serkal syndrome (sex reversal with dysgenesis of kidneys, adrenals and lungs) possibly reflecting increased $5 \alpha$-reductase and loss of function of WNT4 signalling (160).

Males with defects in androgen action may be considered for rearing as female. Mutations in SF-1 should be screened in cases of suspected partial androgen insensitivity when no mutations are found in the androgen receptor gene (161). Mutations in SF-1 have been found in boys with hypospadias or delayed puberty and no history of adrenal failure (162). Mutations in the gene for DAX-1 are found in boys that fail to undergo puberty with hypogonadotrophic hypogonadism and history of neonatal adrenal insufficiency without ambiguous genitalia $(47,48,55)$. GnRH deficiency results from failure of embryonic migration of cells from the olfactory lobe to the forebrain. This is associated with anosmia in most cases (Kallman's syndrome) and five genes have been implicated through mutation analysis of FGFR1, FGF8, PROKR2 and KAL 1 (163) and CHD7 (164). A mutation in the $\mathrm{GnRH}$ receptor gene has been described (165).

Inhibin $\mathrm{B}$ and $\mathrm{AMH}$ are respective markers of Leydig and Sertoli cell function. AMH concentrations are high in the first month of life (3.2-68.5 ng/ml) (166) and fall during childhood up to puberty $(0.5-22.5 \mathrm{ng} / \mathrm{ml})$. AMH is low in gonadal dysgenesis (167), partial androgen insensitivity syndrome and when there are mutations in the gene affecting $\mathrm{AMH}$ production (168). AMH is high when there are defects in testosterone synthesis and complete androgen insensitivity $(167,168)$. Inhibin $B$ is at highest concentrations in infancy $(100-500 \mathrm{~nm} / \mathrm{ml})$, low during childhood $(<50 \mathrm{ng} / \mathrm{ml})$ then rise in the early stages of puberty along with the increase in serum testosterone and testicular volume $(169,170)$. Basal $\mathrm{AMH}$ levels are high in androgen insensitivity syndrome (171).

Puberty is said to be delayed when there are no signs of puberty in boys by the sixteenth year and fourteenth year in girls (172). Complete absence of clinical signs in girls by the fifteenth year warrant investigation. The causes of delayed puberty are many. Gonadotrophin measurements will distinguish primary and secondary forms. The most common problem is isolated gonadotrophin deficiency; in short children this may be constitutional delay of normal puberty. The initial endocrine assessment of amenorrhoea includes 
measurements of prolactin, $\mathrm{FSH}$, $\mathrm{LH}$, oestradiol, TSH, and thyroxine. Hyperthyroidism is occassionally associated with amenorrhoea. When the serum prolactin exceeds $1000 \mathrm{iu} / \mathrm{L}$, a prolactin secreting adenoma needs to be confirmed by appropriate scanning techniques. Hyperprolactinaemia is a cause of arrested puberty and successful medical or surgical treatment will restore regular cycles. Disordered ovarian function presents with primary amenhorroea. In some patients this can co-exist with signs of androgenisation. Body size and degree of exercise are important clinical considerations. Failure to show growth of the uterus on ultrasound also provides valuable diagnostic information. Failure to have a menstrual bleed following a progestogen challenge test is usually a further indication of low oestrogen production (poor follicular growth). A karyotype will exclude Turner syndrome and Turner mosaic. Low serum LH and FSH suggests hypogonadotrophic hypogonadism and these patients can respond well to pulsatile $\mathrm{GnRH}$ treatment. Inactivating mutations of the FSH receptor have been found in a few patients with hypergonadotrophic hypogonadism (173). When LH is raised in the presence of low or normal FSH, the most likely diagnosis is polycystic ovaries (rarely indicative of pregnancy due to reaction of HCG in the LH assay). Patients with PCO may have oligomenorrhoea and have a characteristic ovarian picture on ultrasound, and may have elevated $\mathrm{LH}$ concentrations such that the LH to FSH ratio is 3 or more.

When primary amenorrhoea is associated with hirsutism, measurements of testosterone, DHAS, 17 $\alpha$-hydroxyprogesterone, cortisol and prolactin are required to identify or exclude major causes of abnormal androgen production. Serum testosterone $>5 \mathrm{nmol} / \mathrm{L}$ is indicative of a rare ovarian tumour. DHAS $>20 \mathrm{mmol} / \mathrm{L}$ suggests the possibility of an adrenal androgen secreting tumour. 17 $\alpha$-hydroxyprogesterone $>5 \mathrm{nmol} / \mathrm{L}$ is an indication of some degree of adrenal 21-hydroxylase defect. An ACTH stimulation test with exagerated response of $17 \mathrm{OH}-\mathrm{P}$ is required to confirm this disease. The patient may be a heterozygote for the classical disease or may have a milder form sometimes referred to as late onset $\mathrm{CAH}$. In very specialised laboratories 21-deoxycortisol is a better marker for a defective 21-hydroxylase. These patients can be treated with glucocorticoids.

Delayed puberty in boys requires similar investigations of the hypothalamic-pituitary-gonadal axis. Height and testicular volume should be measured. Serum testosterone shoud be measured early in the morning. Testicular failure can be due to torsion, surgery or inflammation. Gonadotrophin deficiency can be due to syndromes such as Kallman's syndrome, A prolactinoma or pituitary hormone deficiency may be uncovered. A cranial MRI scan may be needed. Prader-Willi and LawrenceMoon-Biedel. Kallman's syndrome is associated with anosmia. During the last 20 years mutations in many genes in $\mathrm{GnRH}$ neuronal embryogenesis (KAL1, GnRHR, FGFR1, GPR54, PROK2, PROK2R, FGF8, CHD7, TAC3, TAC3R, NELF) $(174,175)$ and pituitary development (Prop1, HESX1, POUF1, LHX3, LHX4, SOX2, SOX3) (176-182) have been indentified.

\section{Summary}

This review has covered the clinical problems in children associated with steroid hormones. The excess or absence of cortisol, aldosterone and sex steroids were dealt with in turn so as to rationalise diagnostic tests. The literature cited for reference includes many recent review articles. The laboratory will contribute to future improvements in assays with improved specificity and accuracy that will aid the differential diagnosis of related diseases, elucidate the causes of common clinical problems and further our understanding of developmental milestones such as adrenarche and puberty. The search for genes involved in endocrine function and development continues at a pace and new factors will come to light even between the time of writing this article and publication. This makes a review of this nature difficult to keep totally up to date.

\section{Acknowledgement}

I am grateful to John Achermann (Hospital for Children, Great Ormond Street, London, UK) for criticism, comment and advice on the draft manuscript.

\section{References}

1. Chan LF, Storr HL, Grossman AB, Savage MO. Pediatric Cushing's syndrome: clinical features, diagnosis, and treatment. Ara Bras Endocrinol Metabol 2007;51:1261-1271. [Abstract] / [Full Text]

2. Savage MO, Storr HL, Chan LF, Grossman AB. Diagnosis and treatment of pediatric Cushing's disease. Pituitary 2007;10:365371. [Abstract] / [Full Text] / [PDF]

3. Nieman LK, Biller BM, Findling JW, Newell-Price J, Savage MO, Stewart PM, Montori VM. The diagnosis of Cushing's syndrome: an Endocrine Society Clinical Practice Guideline. $\mathrm{J}$ Clin Endocrinol Metab 2008;93:1526-1540. [Abstract] / [PDF]

4. Batista DL, Riar J Keil M, Stratakis CA. Diagnostic tests for children who are referred for the investiaation of Cushing svndrome. Pediatrics 2007;120:e575-586. [Abstract] / [Full Text] / [PDF]

5. Magiakou MA, Chrousos GP. Cushing's syndrome in children and adolescents: current diagnostic and theraneutic strategies. J Endocrinol Invest 2002;25:181-194. [Abstract] / [Full Text] / [PDF]

6. Hindmarsh PC Brook CG. Single dose dexamethasone suppression test in children: dose relationshin to body size. Clin Endocrinol (Oxf) 1985;23:67-70. [Abstract] / [PDF]

7. Carroll T, Raff H, Findling JW. Late-night salivary cortisol for the diagnosis of Cushina svndrome: a meta-analysis. Endocr Pract 2009;15:335-342. [Abstract]

8. Oliver RL, Davis JR, White A. Characterisation of ACTH related pentides in ectonic Cushing's syndrome. Pituitary 2003;6:119-126. [Abstract] / [PDE]

9. Zemskova MS, Nylen ES, Patronas NJ, Oldfield EH, Becker KL, Nieman LK. Diagnostic accuracy of chromogranin $A$ and calcitonin precursors measurements for the discrimination of ectopic ACTH secretion from Cushing's disease. J Clin Endocrinol Metab. 2009 May 26. [Epub ahead of print] PubMed PMID: 19470624. [Abstract] / [Full Text]

10. Stratakis CA, Boikos SA. Genetics of adrenal tumors associated with Cushing's syndrome: a new classification for bilateral adrenocortical hyperplasias. Nat Clin Pract Endocrinol Metab 2007:3:748-757. [Abstract] / [Full Text] / [PDF]

11. Elamin MB, Murad $M H$, Mullan $R$, Erickson $D$, Harris $K$, Nadeem S, Ennis R, Erwin PJ, Montori VM. Accuracy of diagnostic tests for Cushing's syndrome: a systematic review and metaanalvses. J Clin Endocrinol Metab 2008;93:1553-1562. [Abstract] / [Fül Text] / [PDF] 
Honour JW

Investigations of Steroid Disorders

12. Batista DL, Courcoutsakis N, Riar J, Keil MF Stratakis CA Severe obesity confounds the interpretation of low-dose dexamethasone test combined with the administration of ovine corticotrophin-releasing hormone in childhood Cushing svndrome. J Clin Endocrinol Metab 2008;93:4323-4330. [Ábstract] / [Full Text] / [PDF]

13. Arnaldi G, Tirabassi G, Papa R, Furlani G, Trementino L, Cardinaletti M, Faloia E, Boscaro M. Human corticotropin releasing hormone test performance in the differentia diagnosis between Cushing's disease and pseudo-Cushing state is enhanced by combined ACTH and cortisol analysis. Eur J Endocrinol 2009:160:891-898. [Abstract] / [Full Text] / [PDF]

14. Lienhardt A, Grossman AB, Dacie JE, Evanson J, Huebner A, Afshar F, Plowman PN, Besser GM, Savage MO. Relative contributions of inferior petrosal sinus sampling and pituitary maging in the investigation of children and adolescents with ACTH-dependent Cushing's syndrome. J Clin Endocrinol Metab 2001;86:5711-5714. [Abstract] / [Full Text] / [PDF]

15. Horvath A, Stratakis CA. Unraveling the molecular basis of micronodular adrenal hyperplasia. Curr Onin Endocrinol Diabetes Obes 2008;15:227-233. [Abstract] / [Full Text] / [PDF]

16. Stratakis CA. New genes and/or molecular pathways associated with adrenal hyperplasias and related adrenocortical tumors. Mol Cell Endocrinol 2009;300:152-157. [Abstract] / [Full Text] / [PDF]

17. Stratakis CA, Sarlis N, Kirschner LS, Carney JA, Doppman JL, Nieman LK, Chrousos GP, Papanicolaou DA. Paradoxical response to dexamethasone in the diagnosis of primary pigmented nodular adrenocortical disease. Ann Intern Med 1999;131:585-591. [Abstract] / [Full Text] / [PDF]

18. Gunther DF, Bourdeau I, Matyakhina L, Cassarino D, Kleiner DE, Griffin K, Courkoutsakis N, Abu-Asab M, Tsokos M, Keil M, Carney JA, Stratakis CA. Cyclical Cushing syndrome presenting in infancy: an early form of primary pigmented nodular adrenocortical disease. or a new entitv? J Clin Endocrinol Metab 2004:89:3173-3182. [Abstract] / [Full Text] / [PDF]

19. Dumitrescu CE, Collins MT. McCune-Albright syndrome Orphanet J Rare Dis 2008;3:12. [Abstract] / [Full Text] / [PDF]

20. Lumbroso S, Paris F, Sultan C; European Collaborative Study. Activating Gsalpha mutations: analysis of 113 patients with signs of McCune-Albright syndrome-a European Collaborative Studv. J Clin Endocrinol Metab 2004;89:2107-2113. [Abstract] / [Full Text] / [PDF]

21. Draper N, Walker EA, Bujalska IJ, Tomlinson JW, Chalder SM, Arlt W, Lavery GG, Bedendo O, Ray DW, Laing I, Malunowicz E, White PC, Hewison M, Mason PJ, Connell JM, Shackleton $\mathrm{CH}$, Stewart PM. Mutations in the genes encoding 11 beta-hydroxysteroid dehydrogenase type 1 and hexose-6phosphate dehydrogenase interact to cause cortisone reductase deficiency. Nat Genet 2003;34:434-439. [Abstract] / [Full Text] / [PDF]

22. Jamieson $A$, Wallace AM, Andrew $R$, Nunez BS, Walker BR, Fraser R, White PC, Connell JM. Apparent cortisone reductase deficiency: a functional defect in 11 beta-hydroxysteroid dehydrogenase type 1. J Clin Endocrinol Metab 1999;84:35703574. [Äbstract] / [Full Text] / [PDF]

23. van Rossum EF, Lamberts SW. Glucocorticoid resistance svndrome: A diaanostic and theraneutic annroach. Best Pract Res Clin Endocrinol Metab 2006;20:611-626. [Abstract] / [Full Text] / [PDF]

24. Charmandari E, Kino T, Ichijo T, Chrousos GP. Generalized glucocorticoid resistance: clinical aspects, molecular mechanisms, and implications of a rare aenetic disorder. J Clin Endocrinol Metab 2008:93:1563-1572. [Abstract] / [Full Text] / [PDF]

25. Shamim W, Yousufuddin M, Francis DP, Gualdiero P, Honour JW. Anker SD, Coats AJ. Raised urinary glucocorticoid and adrenal androgen precursors in the urine of young hypertensive patients: possible evidence for partial glucocorticoid resistance. Heart 2001;86:139-144. [Abstract] / [Füll Text] / [PDF]

26. Bornstein SR. Predisposing factors for adrenal insufficiency N Engl J Med 2009;360:2328-2339. [Abstract] / [Full Text] / [PDF]

27. Gassner HL, Toppari J, Quinteiro González S, Miller WL. Near-miss apparent SIDS from adrenal crisis. J Pediatr 2004;145:178-183. [Abstract] / [PDF]

28. Shulman DI, Palmert MR, Kemp SF; Lawson Wilkins Drug and Therapeutics Committee. Adrenal insufficiency: still a cause of morbidity and death in childhood. Pediatrics. 2007;119:e484 494. Epub 2007 Jan 22. [Abstract] / [Full Text]
29. Priftis $K$, Milner AD Conway $E$, Honour JW Adrenal function in asthma. Arch Dis Child 1990;65:838-640. [Abstract] / [PDF]

30. Perry R, Kecha O, Paquette J, Huot C, Van Vliet G, Deal C. Primary adrenal insufficiency in children: twenty years experience at the Sainte-Justine Hospital. Montreal. J Clin Endocrinol Metab 2005;90:3243-3250. [Abstract] / [Full Text] / [PDF]

31. Miller WL. Steroidogenic enzymes. Endocr Dev. 2008:13:1-18. [Abstract] / [PDF]

32. Krone N, Arlt W. Genetics of congenital adrenal hyperplasia. Best Pract Res Clin Endocrinol Metab 2009;23:181-192. [Abstract] / [PDF]

33. Ferraz-de-Souza B, Achermann JC. Disorders of adrenal development. Endocr Dev 2008;13:19-32. [Abstract]

34. Chung TT, Chan LF, Metherell LA, Clark AJ. Phenotypic characteristics of Familial Glucocorticoid Deficiency type 1 and 2. Clin Endocrinol (Oxf) 2009 Jun 24. [Epub ahead of print] [Abstract] / [PDF]

35. Reardon W, Smith A, Honour JW, Hindmarsh $\mathrm{P}$, Das $\mathrm{D}$, Rumsby G, Nelson I, Malcolm S, Adès L, Sillence D, Kumar D, DeLozier-Blanchet C, McKee S, Kelly T, McKeehan WL, Baraitser M, Winter RM. Evidence for digenic inheritance in some cases of Antley-Bixler syndrome? J Med Genet 2000:37:26-32. [Abstract] / [PDF]

36. Kelley RI, Kratz LE, Glaser RL, Netzloff ML, Wolf LM, Jabs EW. Abnormal sterol metabolism in a patient with Antley-Bixler syndrome and ambiquous genitalia. Am J Med Genet 2002:110:95-102. [Abstract] / [Full Text] / [PDF]

37. Miller WL, Huang N, Agrawal V, Giacomini KM. Genetic variation in human P450 oxidoreductase. Mol Cell Endocrinol 2009:300:180-184. [Abstract] / [Full Text] / [PDF]

38. Shackleton C, Marcos J, Malunowicz EM, Szarras-Czapnik M, Jira P, Taylor NF, Murphy N, Crushell E, Gottschalk M, Hauffa B, Cragun DL, Hopkin RJ, Adachi M, Arlt W. Biochemical diagnosis of Antley-Bixler syndrome by steroid analvsis. Am J Med Genet A 2004;128A:223-231. [Abstract] / [Full Text] / [PDF]

39. Wudy SA, Hartmann MF, Draper N, Stewart PM, Arlt W. A male twin infant with skull deformity and elevated neonatal 17-hydroxyprogesterone: a prismatic case of P450 oxidoreductase deficiency. Endocr Res 2004;30:957-964. [Abstract] / [Full Text] / [PDF]

40. Fukami M Nishimura G, Homma $K$, Nagai $T$ Hanaki $K$ Uematsu A, Ishii T, Numakura C, Sawada H, Nakacho M, Kowase T, Motomura K, Haruna H, Nakamura M, Ohishi A, Adachi M, Tajima T, Hasegawa Y, Hasegawa T, Horikawa R, Fujieda K. Ogata T. Cytochrome P450 oxidoreductase deficiency: identification and characterization of biallelic mutations and genotype-phenotype correlations in 35 Japanese patients. J Clin Endocrinol Metab 2009;94:1723-1731. [Abstract] / [Full Text] / [PDF]

41. Hiort $O$, Holterhus PM, Werner R, Marschke C, Hoppe U, Partsch CJ, Riepe FG, Achermann JC, Struve D. Homozygous disruption of P450 side-chain cleavage (CYP11A1) is associated with prematurity, complete $46, X Y$ sex reversal, and severe adrenal failure. J Clin Endocrinol Metab 2005;90:538-541. [Abstract] / [Full Text] / [PDF]

42. Kim CJ, Lin L, Huang N, Quigley CA, AvRuskin TW, Achermann JC, Miller WL. Severe combined adrenal and gonadal deficiency caused by novel mutations in the cholesterol side chain cleavage enzyme. P450scc. J Clin Endocrinol Metab 2008:93:696-702. [Abstract] / [Full Text] / [PDF]

43. Rubtsov P, Karmanov M, Sverdlova P, Spirin P, Tiulpakov A. A novel homozygous mutation in CYP11A1 gene is associated with late-onset adrenal insufficiency and hypospadias in a 46.XY patient. J Clin Endocrinol Metab 2009;94:936-939. [Abstract] / [Full Text] / [PDF]

44. Fujieda K, Okuhara K, Abe S, Tajima T, Mukai T, Nakae J. Molecular pathogenesis of lipoid adrenal hyperplasia and adrenal hypoplasia congenita. J Steroid Biochem Mol Biol 2003:85:483-9. [Abstract] / [PDF]

45. Miller WL. Steroidogenic acute regulatory protein (StAR) novel mitochondrial cholesterol transnorter. Biochim Biophys Acta 2007;1771:663-676. [Abstract] / [PDF]

46. Bas F, Kayserili $H$, Darendeliler F, Uyguner O, Gunoz H, YukselApak M, Atalar F, Bundak R, Wilson RC, New Ml, Wollnik B Saka N. CYP21A2 gene mutations in congenital adrenal hyperplasia: Genotype-phenotype correlation in Turkish children. J Clin Res Ped Endo 2009:1;116-128. [Abstract] / [PDF] 
Honour JW

Investigations of Steroid Disorders

47. Yu RN, Achermann JC, Ito M, Jameson JL. The Role of DAX-1 in Reproduction. Trends Endocrinol Metab 1998;9:169-175. [Abstract] / [PDF]

48. Calliari LE, Longui CA, Rocha MN, Faria CD Kochi C, Melo MR, Melo MB, Monte O. A novel mutation in DAX1 gene causing different phenotvpes in three siblinas with adrenal hvpoplasia congenita. Genet Mol Res 2007;6:177-183. [Abstract] / [Ful Text] / [PDF]

49. Ozer EA, Kaya A, Yildirimer M, Guler O, Can S, Aydinlioglu H. A novel DAX1 gene mutation in a Turkish infant with $X$-linked adrenal hypoplasia congenita. Eur J Pediatr 2009;168:367-369. [Abstract]

50. Yang F, Hanaki K, Kinoshita T, Kawashima Y, Nagaishi J, Kanzaki S. Late-onset adrenal hypoplasia congenita caused by a novel mutation of the DAX-1 gene. Eur J Pediatr 2009;168:329-331. [Abstract] / [Full Text] / [PDF]

51. Landau Z, Hanukoglu A, Sack J, Goldstein N, Weintrob N, Eliakim A, Gillis D, Sagi M, Shomrat R, Kosinovsky EB, Anikster $Y$. Clinical and genetic heterogeneity of congenital adrenal hypoplasia due to NROB1 gene mutations. Clin Endocrinol (Oxf) 2009 Jun 8. [Epub ahead of print] [Abstract] / [PDF]

52. de-Souza BF, Lin L, Achermann JC. Steroidogenic factor-1 (SF-1) and its relevance to pediatric endocrinology. Pediatr Endocrinol Rev 2006;3:359-364. [Abstract]

53. Köhler B, Lin L, Mazen I, Cetindag C, Biebermann H, Akkurt I, Rossi R, Hiort O, Grüters A, Achermann JC. The spectrum of phenotypes associated with mutations in steroidogenic factor 1 (SF-1, NR5A1, Ad4BP) includes severe penoscrotal hypospadias in 46,XY males without adrenal insufficiencv. Eur J Endocrino 2009:161:237-242. [Abstract] / [Full Text] / [PDF]

54. Hoivik EA, Lewis AE, Aumo L, Bakke M. Molecular aspects of steroidogenic factor 1 (SF-1). Mol Cell Endocrinol. 2009 Jul 16. [Evub ahead of print] PubMed PMID: 19616058. [Abstract] / [PDF]

55. Lin L, Hindmarsh PC, Metherell LA, Alzyoud M, Al-Ali M, Brain CE, Clark AJ, Dattani MT, Achermann JC. Severe loss-of-function mutations in the adrenocorticotropin receptor (ACTHR, MC2R) can be found in patients diagnosed with salt-losing adrenal hvvooplasia. Clin Endocrinol (Oxf) 2007;66:205-210. [Äbstract] / [Füll Text] / [PDF]

56. Cooray SN, Chan L, Metherell L, Storr H, Clark AJ. Adrenocorticotropin resistance syndromes. Endocr Dev 2008;13:99-116. [Abstract] / [PDF]

57. Clément $K$, Dubern $B$, Mencarelli $M$, Czernichow $P$, Ito $S$, Wakamatsu K, Barsh GS, Visse C, Leger J. Unexpected endocrine features and normal pigmentation in a young adult patient carrying a novel homozygous mutation in the POMC aene. J Clin Endocrinol Metab 2008;93:4955-4962. [Abstract] [F̈ull Text] / [PDF]

58. Moser HW, Mahmood A, Raymond GV. X-linked adrenoleukodvstrophy. Nat Clin Pract Neurol 2007;3:140-151. [Abstract] / [Full Text]

59. Chang YC, Huang CC, Huang SC, Hung FC. Neonatal adrenoleukodystrophy presenting with seizure at birth: a case report and review of the literature. Pediatr Neurol 2008:38:137-139. [Abstract] / [PDF]

60. Toromanovic A, Tahirovic H, Milenkovic T, Koehler K, Kind B, Zdravkovic D, Hasanhodzic M, Huebner A. Clinical and molecular genetic findings in a 6-year-old Bosnian bov with triple A svndrome. Eur J Pediatr 2009:168:317-320. [Abstract] / [Full Text] / [PDF]

61. Salehi M, Houlden H, Sheikh A, Poretsky L. The diagnosis of adrenal insufficiency in a patient with Allgrove syndrome and a novel mutation in the ALADIN gene. Metabolism 2005;54:200-205. [Abstract] / [PDF]

62. Ryan $A K$, Bartlett $K$, Clayton $P$, Eaton $S$, Mills $L$, Donnai $D$, Winter RM, Burn J. Smith-Lemli-Opitz syndrome: a variable clinical and biochemical phenotype. J Med Genet 1998;35:558-565. [Abstract] / [PDF]

63. Shackleton $\mathrm{CH}$, Roitman E, Kelley R. Neonatal urinary steroids in Smith-Lemli-Opitz syndrome associated with 7-dehydrocholesterol reductase deficiency. Steroids 1999;64:481-490. [Abstract] / [PDF]

64. Restituto P, Galofré JC, Gil MJ, Mugueta C, Santos S, Monreal $\mathrm{JI}$, Varo N. Advantage of salivary cortisol measurements in the diagnosis of glucocorticoid related disorders. Clin Biochem 2008:41:688-692. Epub 2008 Feb 5. [Abstract] / [PDF]
65. Prabhakar VK, Shalet SM. Aetiology, diagnosis, and management of hvnopituitarism in adult life. Postgrad Med J 2006;82:259-266. [Äbstract] / [Full Text] / [PDF]

66. Dinleyici EC, Dogruel N, Acikalin MF, Tokar B, Oztelcan B, Ilhan $\mathrm{H}$. An additional child case of an aldosterone-producing adenoma with an atypical presentation of peripheral paralysis due to hypokalemia. J Endocrinol Invest 2007;30:870-872. [Abstract]

67. Funder JW, Carey RM, Fardella C, Gomez-Sanchez CE, Mantero F,' Stowasser M, Young WF Jr, Montori VM; Endocrine Society. Case detection, diagnosis, and treatment of patients with primary aldosteronism: an endocrine society clinical practice gusideline. I C.lin Endoc.rinol Metab 2008;93:3266-3281. [Abstract] / [Full Text] / [PDF]

68. Oberfield SE, Levine LS, Firpo A, Lawrence D Sr, Stoner E, Levy DJ, Sen S, New MI. Primary hyperaldosteronism in childhood due to unilateral macronodular hvperplasia. Case report. Hypertension 1984;6:75-84. [Abstract]

69. Dewez JE, Bachy A. [A case of primary aldosteronism in childhood] Arch Pediatr 2009;16:37-40. Epub 2008 Nov 20. [Abstract] / [PDF]

70. Dluhy RG Anderson B, Harlin B Ingelfinger J, Lifton R Glucocorticoid-remediable aldosteronism is associated with severe hypertension in early childhood. J Pediatr 2001;138:715-720. [Abstract] / [Full Text] / [PDF]

71. Dluhy RG, Lifton RP. Glucocorticoid-remediable aldosteronism. J Clin Endocrinol Metab 1999;84:4341-4144. [Full Text] / [PDF]

72. Nicod J, Dick B, Frey FJ, Ferrari P. Mutation analysis of CYP11B1 and CYP11B2 in patients with increased 18-hydroxvcortisol production. Mol Cell Endocrinol 2004;214:167-174. [Abstract] / [PDF]

73. Reynolds RM, Shakerdi LA, Sandhu K, Wallace AM, Wood PJ, Walker BR. The utility of three different methods for measuring urinary 18-hydroxycortisol in the differential diagnosis of suspected primary hvperaldosteronism. Eur J Endocrinol 2005;152:903-907. [Abstract] / [Full Text] / [PDF]

74. Lifton RP Dluhy RG, Powers M, Rich GM, Cook S, Ulick S, Lalouel JM. A chimaeric 11 beta-hydroxylase/aldosterone synthase gene causes glucocorticoid-remediable aldosteronism and human hypertension. Nature 1992;355:262-265. [Abstract] / [PDF]

75. Seyberth HW. An improved terminology and classification of Bartter-like svndromes. Nat Clin Pract Nephrol 2008;4:560-567. [Abstract] / [Full Text]

76. Brochard $\mathrm{K}$, Boyer $\mathrm{O}$, Blanchard $\mathrm{A}$, Loirat $\mathrm{C}$, Niaudet $\mathrm{P}$, Macher MA, Deschenes G, Bensman A, Decramer S, Cochat $P$, Morin $D$, Broux $F$, Caillez $M$, Guyot $C$, Novo $R$, Jeunemaitre $X$, Vargas-Poussou R. Phenotype-genotype correlation in antenatal and neonatal variants of Bartter svndrome. Nebhrol Dial Transplant 2009;24:1455-1464. [Abstract] / [Full Text] / [PDF]

77. Godefroid N, Riveira-Munoz E, Saint-Martin C, Nassogne MC, Dahan K, Devuyst O. A novel splicing mutation in SLC12A3 associated with Gitelman svndrome and idiopathic intracranial hypertension. Am J Kidney Dis 2006;48:e73-79. [Abstract] / [Full Text] / [PDF]

78. Rosa S, Duff C, Meyer M, Lang-Muritano M, Balercia G, Boscaro M, Topaloglu AK, Mioni R, Fallo F, Zuliani L, Mantero F', Schoenle EJ, Biason-Lauber A. P450c17 deficiency: clinical and molecular characterization of six patients. J Clin Endocrinol Metab 2007:92:1000-1007. [Abstract] / [Full Text] / [PDF]

79. Nimkarn S, New MI. Steroid 11beta-hydroxylase deficiency congenital adrenal hvnerplasia. Trends Endocrinol Metab 2008:19:96-99. [Abstract] / [PDF]

80. Martin RM, Lin CJ, Costa EM, de Oliveira ML, Carrilho A, Villar $\mathrm{H}$, Longui CA, Mendonca BB. P450c17 deficiency in Brazilian patients: biochemical diagnosis through progesterone levels confirmed by CYP17 genotyping. J Clin Endocrinol Metab 2003;88:5739-5746. [Abstract] / [Fül Text] / [PDF]

81. Wei JQ, Wei JL, Li WC, Bi YS, Wei FC. Genotyping of five chinese patients with 17alpha-hydroxylase deficiency diagnosed through high-performance liquid chromatography serum adrenal profile: identification of two novel CYP17 mutations. J Clin Endocrinol Metab 2006;91:3647-3653. [Abstract] / [Full Text] / [PDF]

82. Hammer F, Stewart PM. Cortisol metabolism in hypertension. Best Pract Res Clin Endocrinol Metab 2006;20:337-353. [Abstract] / [PDF] 
83. Morineau G, Sulmont V, Salomon R, Fiquet-Kempf B, Jeunemaitre X, Nicod J, Ferrari P. Apparent mineralocorticoid excess: report of six new cases and extensive personal experience. J Am Soc Nephrol 2006;17:3176-3184. [Abstract] / [Füll Text] / [PDF]

84. Taylor RL, Machacek D, Singh RJ. Validation of a high-throughput liquid chromatography-tandem mass spectrometry method for urinarv cortisol and cortisone. Clin Chem 2002;48:1511-1519. [Abstract] / [Full Text] / [PDF]

85. Kushnir MM, Neilson R, Roberts WL, Rockwood AL. Cortisol and cortisone analysis in serum and plasma by atmospheric pressure photoionization tandem mass spectrometry. Clin Biochem 2004:37:357-362. [Abstract] / [PDF]

86. Rauh M, Gröschl M, Rascher W, Dörr HG. Automated, fast and sensitive quantification of 17 alpha-hydroxy-progesterone, androstenedione and testosterone by tandem mass spectrometry with on-line extraction. Steroids 2006:71:450-458. [Abstract] / [PDF]

87. De Palo EF, Antonelli G, Benetazzo A, Prearo M, Gatti R. Human saliva cortisone and cortisol simultaneous analysis using reverse phase HPLC technique. Clin Chim Acta $2009 ; 405: 60-65$. [Abstract] / [PDF]

88. Turpeinen $U$, Markkanen $\mathrm{H}$, Sane $T$, Hämäläinen E. Determination of free tetrahydrocortisol and tetrahydrocortisone ratio in urine by liquid chromatography-tandem mass spectrometrv. Scand J Clin Lab Invest 2006;66:147-159. [Abstract] / [Full Text] / [PDF]

89. Dellow EL, Unwin RJ, Honour JW. Pontefract cakes can be bad for you: refractory hypertension and liauorice excess. Nephrol Dial Transplant 1999;14:218-220. [Abstract] / [PDF]

90. Fiselier T, Monnens L, van Munster $P$, Jansen M, Peer $P$, Lijnen $P$. The renin-angiotensin-aldosterone system in infancy and childhood in basal conditions and after stimulation. Eur $\mathrm{J}$ Pediatr 1984;143:18-24. [PDF]

91. Riepe FG, Krone N, Peter M, Sippell WG, Partsch CJ. Chromatographic system for the simultaneous measurement of plasma 18-hydroxy-11-deoxycorticosterone and 18-hydroxycorticosterone by radioimmunoassay: reference data for neonates and infants and its application in aldosterone-synthase deficiency. J Chromatogr B Analyt Technol Biomed Life Sci 2003;785:293-301. [Abstract] / [PDF]

92. Shackleton $\mathrm{CH}$, Honour JW. Identification and measurement of 18-hydroxycorticosterone metabolites by gas chromatographymass spectrometry. J Steroid Biochem 1977:8:199-203. [Abstract] / [PDF]

93. Nguyen HH, Hannemann F, Hartmann MF, Wudy SA, Bernhardt R. Aldosterone synthase deficiency caused by a homozygous L451F mutation in the CYP11B2 gene. Mol Genet Metab 2008:93:458-467. [Abstract] / [PDF]

94. Riepe FG, Finkeldei J, de Sanctis L, Einaudi S, Testa A, Karges B, Peter M, Viemann M, Grötzinger J, Sippell WG, Fejes-Toth G' Krone $\mathrm{N}$. Elucidating the underlying molecular pathogenesis of NR3C2 mutants causing autosomal dominant pseudohypoaldosteronism type 1. J Clin Endocrinol Metab 2006;91:4552-4561. [Abstract] / [Full Text] / [PDF]

95. Pujo L, Fagart J, Gary F, Papadimitriou DT, Claës A, Jeunemaitre X, Zennaro MC. Mineralocorticoid receptor mutations are the principal cause of renal tvpe 1 pseudohvpoaldosteronism. Hum Mutat 2007:28:33-40. [Abstract] / [PDF]

96. Balsamo A, Cicognani A, Gennari M, Sippell WG, Menabò S, Baronio F, Riepe FG. Functional characterization of naturally occurring NR3C2 gene mutations in Italian patients suffering from pseudohypoaldosteronism tvpe 1. Eur J Endocrino 2007;156:249-256. [Abstract] / [Full Text] / [PDF]

97. Uchida N, Shiohara M, Miyagawa S, Yokota I, Mori T. A novel nonsense mutation of the mineralocorticoid receptor gene in the renal form of pseudohypoaldosteronism type 1. J Pediatr Endocrinol Metab 2009;22:91-95. [Abstract]

98. Belot A, Ranchin B, Fichtner C, Pujo L, Rossier BC, Liutkus A Morlat C, Nicolino M, Zennaro MC, Cochat P. Pseudohypoaldosteronisms, report on a 10-patient series. Nephrol Dial Transplant 2008;23:1636-1641. [Abstract] / [Full Text] / [PDF]

99. Hanukoglu A Edelheit O, Shriki Y, Gizewska M, Dascal N Hanukoglu I. Renin-aldosterone response, urinary $\mathrm{Na} / \mathrm{K}$ ratio and growth in pseudohypoaldosteronism patients with mutations in epithelial sodium channel (ENaC) subunit aenes. J Steroid Biochem Mol Biol 2008;111:268-274. [Abstract] / [PDF]
100. Honour JW, Dillon MJ, Shackleton $\mathrm{CH}$. Analysis of steroids in urine for differentiation of pseudohypoaldosteronism and aldosterone biosynthetic defect. J Clin Endocrinol Metab 1982;54:325-331. [Abstract] / [PDF]

101. Kuhnle U, Keller U, Armanini D, Funder J, Krozowski Z. Immunofluorescence of mineralocorticoid receptors in peripheral lymphocytes: presence of receptor-like activity in patients with the autosomal dominant form of pseudohypoaldosteronism, and its absence in the recessive form. J Steroid Biochem Mol Biol 1994:51:267-273. [Abstract] / [PDF]

102. Honour JW, Valman HB, Shackleton HL. Aldosterone and sodium homeostasis in preterm infants. Acta Paediatr Scand 1977:66:103-109. [Abstract] / [PDF]

103. Martinerie L, Pussard E, Foix-L-hélias L, Petit F, Cosson C, Boileau P, Lombès M. Physiological Partial Aldosterone Resistance in Human Newborns. Pediatr Res 2009 Jun 17. [Epub ahead of print] [Abstract]

104. Martinerie L, Viengchareun S, Delezoide AL, Jaubert F, Sinico $M$. Prevot $S$, Boileau $P$, Meduri $G$, Lombès $M$. Low Renal Mineralocorticoid Receptor Expression at Birth Contributes to Partial Aldosterone Resistance in Neonates. Endocrinologv 2009 May 28. [Epub ahead of print] [Abstract] / [Full Text] / [PDF]

105. Jones ME, Boon WC, Mclnnes K, Maffei L, Carani C, Simpson ER. Recognizing rare disorders: aromatase deficiency. Nat Clin Pract Endocrinol Metab 2007;3:414-421. [Abstract] / [PDF]

106. Maciel-Guerra AT, de Mello MP, Coeli FB, Ribeiro ML, Miranda ML, Marques-de-Faria AP, Baptista MT, Moraes SG, GuerraJúnior G. XX Maleness and XX true hermaphroditism in SRYnegative monozygotic twins: additional evidence for a common oriain. J Clin Endocrinol Metab 2008;93:339-343. [Abstract] [Full Text] / [PDF]

107. Wong T, Shackleton $\mathrm{CH}$, Covey TR, Ellis G. Identification of the steroids in neonatal plasma that interfere with 17alpha-hydroxyprogesterone radioimmunoassays. Clin Chem 1992;38:18301837. [Abstract] / [PDF]

108. Wallace AM, Beesley J, Thomson M, Giles CA, Ross AM, Taylor NF. Adrenal status during the first month of life in mature and premature human infants. J Endocrinol 1987;112:473-480. [Abstract] / [PDF]

109. Hughes IA, Arisaka O, Perry LA, Honour JW. Early diagnosis of 11 beta-hydroxylase deficiency in two siblings confirmed by analysis of a novel steroid metabolite in newborn urine. Acta Endocrinol (Copenh) 1986;111:349-354. [Abstract] / [Full Text]

110. Wudy SA Hartmann MF. Gas chromatography-mass spectrometry profiling of steroids in times of molecular bioloay. Horm Metab Res 2004;36:415-422. [Abstract] / [Full Text] / [PDF]

111. Holst JP, Soldin SJ, Tractenberg RE, Guo T, Kundra P, Verbalis $J G$, Jonklaas J. Use of steroid profiles in determining the cause of adrenal insufficiency. Steroids 2007;72:71-84. [Fuill Text]

112. Guo T, Taylor RL, Singh RJ, Soldin SJ. Simultaneous determination of 12 steroids by isotope dilution liquid chromatography-photospray ionization tandem mass spectrometry. Clin Chim Acta 2006;372:76-82. [Abstract] / [PDF]

113. Kushnir MM, Rockwood AL, Roberts WL, Pattison EG, Owen WE, Bunker AM, Meikle AW. Development and performance evaluation of a tandem mass spectrometrv assav for 4 adrenal steroids. Clin Chem 2006;52:1559-1567. [Abstract] / [Full Text]/ [PDF]

114. Rauh M. Steroid measurement with LC-MS/MS in pediatric endocrinoloav. Mol Cell Endocrinol 2009;301:272-281. [Abstract] / [PDF]

115. Cavarzere P, Samara-Boustani D, Flechtner I, Dechaux M, Elie C, Tardy V, Morel Y, Polak M. Transient hyper-17-hydroxyprogesteronemia: a clinical subgroup of patients diagnosed at neonatal screening for congenital adrenal hvperplasia. Eur $\mathrm{J}$ Endocrinol 2009;161:285-292. [Abstract] / [Full Text] / [PDF]

116. Fingerhut $R$. False positive rate in newborn screening for congenital adrenal hyperplasia (CAH)-ether extraction reveals two distinct reasons for elevated 17alpha-hydroxvprogesterone (17-OHP) values. Steroids 2009;74:662-665. [Abstract] / [PDF]

117. Janzen $N$, Peter $M$, Sander $S$, Steuerwald $U$, Terhardt $M$ Holtkamp U, Sander J. Newborn screening for congenital adrenal hyperplasia: additional steroid profile using liquid chromatography-tandem mass spectrometrv. J Clin Endocrinol Metab 2007;92:2581-2589. [Abstract] / [Full Text] / [PDF] 
Honour JW

Investigations of Steroid Disorders

118. Higashi T, Nishio T, Uchida S, Shimada K, Fukushi M, Maeda M. Simultaneous determination of 17alpha-hydroxypregnenolone and 17alpha-hydroxyprogesterone in dried blood spots from low birth weight infants using LC-MS/MS. J Pharm Biomed Anal 2008;48:177-182. [Abstract] / [PDF]

119. Schwarz E, Liu A, Randall H, Haslip C, Keune F, Murray M, Longo N. Pasquali M. Use of Steroid Profiling by UPLC-MS/MS as a Second Tier Test in Newborn Screening for Congenita Adrenal Hyperplasia: the Utah exnerience. Pediatr Res 2009 Apr 22. [Epub ahead of print] [Abstract]

120. Appan S, Hindmarsh PC, Brook CG. Monitoring treatment in congenital adrenal hvnerplasia. Arch Dis Child. 1989;64:12351239. [Abstract] / [PDF̈]

121. Berberoglu M. Precocious puberty and normal variant puberty: Definition etiology, diagnosis and current management. J Clin Res Ped Endo 2009:1:164-174. [Abstract] / [PDF]

122. Traggiai C, Stanhope R. Disorders of pubertal develonment. Best Pract Res Clin Obstet Gynaecol 2003;17:41-56. [Abstract] / [PDF]

123. Carel JC, Léger J. Clinical practice. Precocious pubertv. N Engl J Med 2008:358:2366-2377. [Abstract] / [Full Text] / [P'DF]

124. Segal DG, DiMeglio LA, Ryder KW, Vollmer PA, Pescovitz OH. Assay interference leading to misdiagnosis of centra precocious puberty. Endocrine 2003;20:195-199. [Abstract]/ IPDF

125. Andersson M, Rönnmark J, Areström I, Nygren PA, Ahlborg N. Inclusion of a non-immunoglobulin binding protein in two-site ELISA for quantification of human serum proteins without interference by heterophilic serum antibodies. J Immuno Methods 2003:283:225-234. [Abstract] / [PDF]

126. Zhang Y, Zhang Z, Yang F. Non-competitive immunoassay for luteinizing hormonein human serum using capillary electrophoresis with chemiluminescence detection Luminescence 2007:22:511-517. [Abstractl / [PDF]

127. Honour JW, Price DA, Taylor NF, Marsden HB, Grant DB Steroid biochemistry of virilising adrenal tumours in childhood. Eur J Pediatr 1984;142165-169. [Abstract]

128. Wolthers OD, Cameron FJ, Scheimberg I, Honour JW, Hindmarsh PC, Savage MO, Stanhope RG, Brook CG. Androgen secreting adrenocortical tumours. Arch Dis Child 1999;80:46-50. [Abstract] / [Full Text] / [PDF]

129. Noordam C, Dhir V, McNelis JC, Schlereth F, Hanley NA, Krone $N$, Smeitink JA, Smeets R, Sweep FC, Claahsen-van der Grinten $\mathrm{HL}$, Arlt W. Inactivating PAPSS2 mutations in a patient with premature nubarche. N Engl J Med 2009:360:2310-2318. [Abstract] / [Full Text] / [PDF]

130. Bidet M, Bellanné-Chantelot C, Galand-Portier MB, Tardy V, Billaud L, Laborde K, Coussieu C, Morel Y, Vaury C, Golmard JL, Claustre A, Mornet E, Chakhtoura Z, Mowszowicz I, Bachelot A, Touraine P. Kuttenn F. Clinical and molecular characterization of a cohort of 161 unrelated women with nonclassical congenital adrenal hyperplasia due to 21-hydroxylase deficiency and 330 familv members. J Clin Endocrinol Metab 2009:94:1570-1578. [Abstract] / [Full Text] / [PDF]

131. Lin-Su K, Nimkarn S, New MI. Congenital adrenal hyperplasia in adolescents: diagnosis and management. Ann N Y Acad Sci 2008:1135:95-98. [Abstract] / [PDF]

132. Pang SY, Lerner AJ, Stoner E, Levine LS, Oberfield SE, Engel I, New MI. Late-onset adrenal steroid 3 beta-hydroxysteroid dehydrogenase deficiency. I. A cause of hirsutism in pubertal and postpubertal women. J Clin Endocrinol Metab 1985;60:428-439. [Abstract] / [PDF]

133. Carbunaru G, Prasad P, Scoccia B, Shea P, Hopwood N, Ziai F, Chang YT, Myers SE, Mason JI, Pang S. The hormonal phenotype of Nonclassic 3 beta-hydroxysteroid dehydrogenase (HSD3B) deficiency in hyperandrogenic females is associated with insuin-resistant polycystic ovary syndrome and is not a variant of inherited HSD3B2 deficiencv. J Clin Endocrinol Metab 2004:89:783-794. [Abstract] / [Full Text] / [PDF]

134. Mermejo LM, Elias LL, Marui S, Moreira AC, Mendonca BB, de Castro M. Refining hormonal diagnosis of type II 3betahydroxysteroid dehydrogenase deficiency in patients with premature pubarche and hirsutism based on HSD3B2 genotvping. J Clin Endocrinol Metab 2005;90:1287-1293. [̈Abstract] / [Full Text] / [PDF]

135. Borges MF, Pacheco KD, Oliveira AA, Rita CV, Pacheco KD Resende EA, Lara BH, Ferreira BP. Premature thelarche: clinical and laboratorial assessment by immunochemiluminescent assav. Ara Bras Endocrinol Metabol 2008;52:93-100. [Abstract] / [Fuli Text]
136. Zevenhuijzen H, Kelnar CJ, Crofton PM. Diagnostic utility of a low-dose gonadotronin-releasing hormone test in the context of puberty disorders. Horm Res 2004;62:168-176. [Abstract] / [Ful| Text] / [PDF]

137. Resende EA, Lara BH, Reis JD, Ferreira BP, Pereira GA, Borges MF. Assessment of basal and gonadotropin-releasing hormone-stimulated gonadotropins by immunochemiluminometric and immunofluorometric assavs in normal children J Clin Endocrinol Metab 2007;92:1424-1429. [Abstract] / [Full Text] / [PDF]

138. Tiosano D Knopf C Koren I Levanon N Hartmann MF Hochberg Z. Wudy SA. Metabolic evidence for impaired 17alpha-hydroxylase activity in a kindred bearing the E305G mutation for isolate 17.20-lyase activity. Eur J Endocrinol 2008;158:385-392. [Abstract] / [Full Text] / [PDF]

139. Dean HJ, Shackleton $\mathrm{CH}$, Winter JS. Diagnosis and natural history of 17-hydroxylase deficiency in a newborn male. J Clin Endocrinol Metab 1984;59:513-20. [Abstract] / [PDF]

140. Qiao J, Chen X, Zuo CL, Gu YY, Liu BL, Liang J, Lu YL, Tang JF, Wu YX, Chen MD, Chen JL, Wu WL, Song HD. Identification of steroid biosynthetic defects in genotype-proven heterozygous individuals for 17alpha-hydroxylase/17,20- lyase deficiencv. Clin Endocrinol (Oxf) 2009. [Epub ahead of print] [Abstract] / [PDF]

141. Welzel M, Wüstemann N, Simic-Schleicher G, Dörr HG, Schulze E, Shaikh G, Clayton P, Grötzinger J, Holterhus PM, Riepe FG. Carboxyl-terminal mutations in 3beta-hydroxysteroid dehydrogenase type II cause severe salt-wasting congenital adrenal hvperplasia. J Clin Endocrinol Metab 2008;93:14181425. [Abstract] / [Full Text] / [PDF]

142. Shackleton $\mathrm{CH}$, Roitman $\mathrm{E}$, Kelley R. Neonatal urinary steroids in Smith-Lemli-Opitz syndrome associated with 7-dehydrocholesterol reductase deficiency. Steroids 1999;64:481-490. [Abstract] / [PDF]

143. Kossack N, Simoni M, Richter-Unruh A, Themmen AP, Gromoll $J$. Mutations in a novel, cryptic exon of the luteinizing hormone/chorionic gonadotropin receptor gene cause male pseudohermaphroditism. PLoS Med 2008;5):e88. [Full Text] / [PDF]

144. Qiao J, Han B, Liu BL, Chen X, Ru Y, Cheng KX, Chen FG, Zhao SX, Liang J, Lu YL, Tang JF, Wu YX, Wu WL, Chen JL, Chen MD, Song HD. A splice site mutation combined with a novel missense mutation of LHCGR cause male pseudohermanhroditism. Hum Mutat 2009 Jun 23. [Epub ahead of print] [Abstract] / [PDF]

145. Boehmer AL, Brinkmann AO, Sandkuijl LA, Halley DJ, Niermeijer MF, Andersson $S$, de Jong FH, Kayserili $H^{\prime}$, de Vroede MA, Otten BJ, Rouwé CW, Mendonça BB, Rodrigues C, Bode $\mathrm{HH}$, de Ruiter PE, Delemarre-van de Waal HA, Drop SL. 17Beta-hydroxysteroid dehydrogenase-3 deficiency: diagnosis, phenotypic variability, population genetics, and worldwide distribution of ancient and de novo mutations. J Clin Endocrinol Metab 1999:84:4713-21. [Abstract] / [Full Text] / [PDF]

146. Lee YS, Kirk JM, Stanhope RG, Johnston DI, Harland S, Auchus RJ, Andersson S, Hughes IA. Phenotypic variability in 17betahvdroxvsteroid dehvdrogenase-3 deficiency and diagnostic pitfalls. Clin Endocrinol (Oxf) 2007;67:20-28. [Abstract] / [Full Text] / [PDF]

147. Faienza MF Giordani L, Delvecchio M Cavallo L Clinical endocrine, and molecular findings in 17beta-hydroxysteroid dehydrogenase tvpe 3 deficiency. J Endocrinol Invest 2008;31:85-91. [Abstract]

148. Gallagher LM, Owen LJ, Keevil BG. Simultaneous determination of androstenedione and testosterone in human serum by liquid chromatography-tandem mass spectrometry. Ann Clin Biochem 2007:44:48-56. [Abstract] / [PDF]

149. Licea-Perez H, Wang S, Szapacs ME, Yang E. Development of a highly sensitive and selective UPLC/MS/MS method for the simultaneous determination of testosterone and 5alphadihydrotestosterone in human serum to support testosterone replacement theranv for hypogonadism. Steroids 2008;73:601-610. [Abstract] / [PDF]

150. Wang C, Shiraishi S, Leung A, Baravarian S, Hull L, Goh V, Lee PW, Swerdloff RS. Validation of a testosterone and dihydrotestosterone liquid chromatography tandem mass spectrometry assay: Interference and comparison with established methods. Steroids 2008:73:1345-1352. [Abstract] / [PDF] 
Honour JW

Investigations of Steroid Disorders

151. Shiraishi S, Lee PW, Leung A, Goh VH, Swerdloff RS, Wang C. Simultaneous measurement of serum testosterone and dihydrotestosterone by liquid chromatographv-tandem mass spectrometry. Clin Chem 2008;54:1855-1863. [Ábstract] / [PDF]

152. Bouvattier C, Carel JC, Lecointre C, David A, Sultan C, Bertrand AM, Morel $Y$, Chaussain JL. Postnatal changes of $T, L H$, and $\mathrm{FSH}$ in $46, X Y$ infants with mutations in the AR gene. $J$ Clin Endocrinol Metab 2002;87:29-32. [Abstract] / [Full Text] / [PDF]

153. Mazen I, Lumbroso S, Abdel Ghaffar S, Salah N, Sultan C Mutation of the androgen receptor (R840S) in an Egyptian patient with partial androgen insensitivity syndrome: review of the literature on the clinical expression of different R840 substitutions. J Endocrinol Invest 2004;27:57-60. [Abstract]

154. Nicoletti A, Baldazzi L, Balsamo A, Barp L, Pirazzoli P, Gennari M, Radetti G, Cacciari E, Cicognani A. SRD5A2 gene analysis in an Italian population of under-masculinized $46, \mathrm{XY}$ subjects. Clin Endocrinol (Oxf) 2005;63:375-380. [Abstract] / [PDF]

155. Boehmer $A L$, Brinkmann $O$, Brüggenwirth $H$, van Assendelft $C$ Otten BJ, Verleun-Mooijman MC, Niermeijer MF, Brunner HG, Rouwé CW, Waelkens JJ, Oostdijk W, Kleijer WJ, van der Kwast TH, de Vroede MA, Drop SL. Genotype versus phenotype in families with androgen insensitivity syndrome. J Clin Endocrinol Metab 2001:86:4151-160. Erratum in: J Clin Endocrinol Metab 2002;87:3109. [Abstract] / [Full Text] / [PDF]

156. Barbaro M, Oscarson M, Almskog I, Hamberg $H$, Wedell A Complete androgen insensitivity without Wolffian duct development: the AR-A form of the androgen receptor is not sufficient for male genital develonment. Clin Endocrinol (Oxf) 2007;66:822-826. [Abstract] / [PDF]

157. Jeske YW, McGown IN, Cowley DM, Oley C, Thomsett MJ, Choong CS, Cotterill AM. Androgen receptor genotyping in a large Australasian cohort with androgen insensitivity syndrome identification of four novel mutations. J Pediatr Endocrino Metab 2007:20:893-908. [Abstract]

158. Deeb $A$, Jääskeläinen J, Dattani $M$, Whitaker HC, Costigan $C$ Hughes IA. A novel mutation in the human androgen receptor suggests a regulatory role for the hinge region in aminoterminal and carboxy-terminal interactions. J Clin Endocrino Metab 2008;93:3691-3696. [Abstract] / [Full Text] / [PDF]

159. Philibert P, Audran F, Pienkowski C, Morange I, Kohler B Flori E, Heinrich C, Dacou-Voutetakis C, Joseph MG,

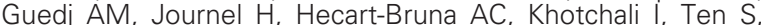
Bouchard P, Paris F, Sultan C. Complete androgen insensitivity syndrome is frequently due to premature stop codons in exon 1 of the androgen receptor gene: an international collaborative report of 13 new mutations. Fertil Steril 2009 May 20. [Epub ahead of print] [Abstract] / [Full Text] / [PDF]

160. Mandel H, Shemer R, Borochowitz ZU, Okopnik M, Knopf C Indelman $M$, Drugan A, Tiosano D, Gershoni-Baruch R, Choder $M$, Sprecher E. SERKAL syndrome: an autosomal-recessive disorder caused by a loss-of-function mutation in WNT4. Am J Hum Genet 2008;82:39-47. [Abstract] / [Full Text]

161. Coutant R, Mallet D, Lahlou N, Bouhours-Nouet N, Guichet A Coupris L, Croué A, Morel Y. Heterozygous mutation of steroidogenic factor- 1 in $46 \mathrm{XY}$ subjects may mimic partial androgen insensitivitv svndrome. J Clin Endocrinol Metab 2007:92:2868-2873. [Ábstract] / [Full Text] / [PDF]

162. Koehler B, Lin L, Mazen I, Cetindag C, Biebermann H, Akkurt I, Rossi R, Hiort O, Grueters A, Achermann J. The spectrum of phenotypes associated with mutations in steroidogenic factor 1(SF-1, NR5A1, Ad4BP) includes severe penoscrotal hypospadias in 46,XY males without adrenal insufficiency. Eur J Endocrino 2009 May 13. [Epub ahead of print] [Abstract] / [Full Text] / [PDF]

163. Hardelin JP Dodé C. The complex genetics of Kallmann syndrome: KAL1, FGFR1.FGF8, PROKR2, PROK2, et al. Sex Dev 2008;2:181-193. [Abstract] / [PDF]

164. Jongmans MC, van Ravenswaaij-Arts CM, Pitteloud N, Ogata T, Sato N, Claahsen-van der Grinten $\mathrm{HL}$, van der Donk $\mathrm{K}$ Seminara S, Bergman JE, Brunner HG, Crowley WF Jr, Hoefsloot LH. CHD7 mutations in patients initially diagnosed with Kallmann syndrome-the clinical overlan with CHARGE syndrome. Clin Genet 2009:75:65-71. [Abstract] / [PDF]

165. Bouligand J, Ghervan C, Tello JA, Brailly-Tabard S, Salenave S, Chanson P,Lombès M, Millar RP, Guiochon-Mantel A, Young J. Isolated familial hvnoaonadotronic hvnoaonadism and a GNRH1 mutation. N Engl J Med 2009;360:2742-2748. [Abstract] / [Full Text] / [PDF]
166. Lee MM, Misra M, Donahoe PK, MacLaughlin DT MIS/AMH in the assessment of cryptorchidism and intersex conditions. Mol Cell Endocrinol 2003;211:91-98. [Abstract] / [PDF]

167. Rey RA, Belville C, Nihoul-Fékété C, Michel-Calemard L, Forest MG, Lahlou N, Jaubert F, Mowszowicz I, David M, Saka N, Bouvattier C, Bertrand AM, Lecointre C, Soskin S, Cabrol S, Crosnier H, Léger J, Lortat-Jacob S, Nicolino M, Rabl W, Toledo SP, Baş F, Gompel A, Czernichow P, Chatelain P, RRappaport P, More Y, Josso N. Evaluation of gonadal function in 107 intersex patients by means of serum antimüllerian hormone meas'irement. J Clinir Endocrinol Metab 1999:84:627-631. [A bctract] / [Full Tox+1 / [PDF]

168. Josso N, Belville C, di Clemente N, Picard JY. AMH and AMH receptor defects in persistent Müllerian duct syndrome. Hum Reprod Update. 2005;11:351-6. [Abstract] / [Full Text] / [PDF]

169. Radicioni AF, Anzuini A, De Marco E, Nofroni I, Castracane VD, Lenzi $A$. Changes in seruın nnibin $\bar{B}$ curing normal male

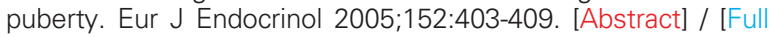
Text] / [PDF]

170. Bergadá I, Mılanı C, Bedecarrás P, Andreone L, Ropelato MIG, Gottliek S, Bergadá C, Campo S, Rey RA. Time course of the serum gonadotropın surge, Inhıbıns, and antı-IVlullerıan hormone in normal newborn males during the first month of life. J Clin Endocrinol Metab 2006;91:4092-4098. [Abstract] / [Full Text] / [PDF]

171. Kubini K. Zachmann M, Albers N, Hiort O, Bettendorf IM, INölfle J, Biclling naier $F$, Klingmüller D. Basal inhibin B and the testosterone response to human chorionic gonadotropin correlate in prepubertal boys. J Clin Endocrinol Metab 2000;85:134-138. [Abstract] / [Full Text] / [PDF]

172. Traggiai C, Stanhone R. Dolay'ed puherty. Best Pract Res Clin

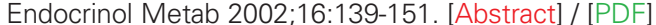

173. Allen LA, Achermann JC, Pakarinen P, Kotlar TJ, Luhtaniemi IT, Jameson JL, Cheetham TD, Ball SG. A novel lcse of function mutation in exon 10 of the FSH receptor gene causing hypergonadotrophic hypogonadism: clinical and molecular characteristics. Hum Reprod 2003;18:251-256. [Abstract] / [Ful] Texi] i [FDFr]

174. Pedersen-vi/hite JR, Chorich LP, Bick DP, Sherīis Ru', Layman

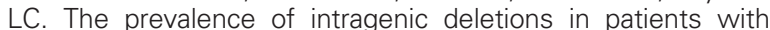
idiopathic hypogonadotropic hypogonadism and Kallmann syndrome. Mol Hum Reprod 2008;14:367-370. [Abstract] / [PDF]

175. I3hangoo A, Jacobson-Dickman E. The genetics of Idıopathic hypogonadotropic hypogonadism:unraveling the biology of human sexual development. Pediatr Endocrinol Rev 2009;6:395-404. [Abstract]

176. I'im HG, Bhagavath B, Layman LC. Clinical manifestations of impaired $\mathrm{GnRH}$ neuron development and function. Neurosignals 2008;16:165-182. [Abstract] / [Full Text]

177. Kim SH, Hu Y, Cadman S, Bouloux P. Diversity in fibroblast growth factor receptor 1 regulation: learning from the investigation of Kallmann syndrome. J Neuroendocrinol 2008;20:141-163. [^. hetract]

178. Tziaferi V, Kelberrnan $\mathrm{n}$. Dattani MT. The role of SOX2 in hypogonadotropic hypogonadism. Sex Dev 2008;2:194-199. [A

179. Dattani MT. Tho candicate gene approach to the diagnosis of monogenic disorders. Horm Res 2009;71 Suppl 2:14-21.

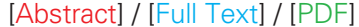

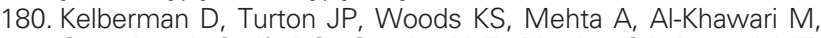
Greening J, Swift PG, Otonkoski T, Rhodes SJ, Dattani MT. Molecular analysis of novel PROP1 mutations associated with combined pituitary hormone deficiency (CPHD). Clin Endocrinol (Oxf) 2009;70:96-103. [Abstract] / [rull I ext] / [PUト]

181. Kelberman D, Dattani ivīi. Kole of transcription factors in midline central nervous system and pituitary defects. Endocr Dev 2009:14:67-82. [Abstract] / [PDF]

182. Colvin SC, Mullen RD, Pfaeftle RW, Rhodes SJ. LHX3 and LHX4 transcription factors in pituitary development and disease. Pediatr Endocrinol Rev 2009;6(Suppl 2):283-290. [Abstract] 